University of San Diego

Digital USD

1998

\title{
Transborder Economic Development: A Collaborative Partnership in the San Diego-Tijuana Region
}

Piedad Garcia EdD

University of San Diego

Follow this and additional works at: https://digital.sandiego.edu/dissertations

Part of the Leadership Studies Commons

\section{Digital USD Citation}

Garcia, Piedad EdD, "Transborder Economic Development: A Collaborative Partnership in the San DiegoTijuana Region" (1998). Dissertations. 638.

https://digital.sandiego.edu/dissertations/638

This Dissertation: Open Access is brought to you for free and open access by the Theses and Dissertations at Digital USD. It has been accepted for inclusion in Dissertations by an authorized administrator of Digital USD. For more information, please contact digital@sandiego.edu. 


\section{TRANSBORDER ECONOMIC DEVELOPMENT: A COLLABORATIVE PARTNERSHIP \\ THE SAN DIEGO-TIJUANA REGION}

by

Piedad Garcia

A dissertation submitted in partial fulfillment

of the requirements for the degree of

Doctor in Education

Leadership studies

University of San Diego

1998

\section{Dissertation committee}

Mary Abascal-Hildebrand, Ed.D.

Daniel Tolf, J.D

Frank Medeiros, Ph.D. 


\section{ABSTRACT OF THE DISSERTATION}

Transborder Economic Development a Collaborative Partnership in the San Diego-Tijuana Region

Garcia, Piedad, Ed.D. University of San Diego, 1998, 158 pp. Director: Mary Abascal-Hildebrand, Ed.D.

The study seeks to understand and develop insights into the San Diego-Tijuana transborder economic collaborative partnership, by examining the Binational Planning and Coordination Committee (BPCC). This entity was established in 1993 via a Letter of Agreement between the City of San Diego and the municipality of Tijuana. Pursuant to the Letter of Agreement the BPCC is examined against the backdrop of the global economy, the emergence of region-states, U.S.-Mexico relations and transborder relations in the San Diego-Tijuana region.

A qualitative single case-study methodology is applied to explain the role, function, structure, decision making processes and collaborative leadership relationships of the BPCC. The study also addresses the perceived need by some to create sustainable economic development strategies for the region and the necessity to establish a structure that has a broad range of powers and can consolidate the multiple initiatives that exist in the San Diego-Tijuana region. Three themes are identified and synthesized in the analysis 
of the BPCC, revealing: a) the need for an agenda: how the structure of the BPCC facilitates the purpose and objectives of the Letter of Agreement and how restructuring and/or developing a new institutional entity may facilitate a new economic agenda for the transborder region; b) the need for sustainable economic development strategies; and c) the need for collaboration: the relational importance of transborder collaborative leadership relationships.

The findings support the need for the San Diego-Tijuana region to establish a dialogue with the stakeholders and policymakers of the region on the future direction of the transborder region. The need to restructure the BPCC and /or develop a new overarching structure that would facilitate a new economic agenda for the transborder region is an issue that the San Diego-Tijuana region has to explore in order to respond to the market demands of the region and the global economy. 
This endeavor is dedicated to my parents Antonio and Lilia Garcia for their support, understanding and unyielding love and care during this journey. Muchas gracias $y$ los quiero muchisimo.

To my friends who stood by my side, for holding my hand and encouraging me when in doubt, I thank you ever so much for your patience as I pursued new horizons.

Lastly, this work is dedicated to all of the visionaries of the San Diego-Tijuana region for their foresight, and your courage to venture into uncharted territory and rising to the challenge that lies ahead. 


\section{ACKNOWLEDGMENTS}

The culmination of this work would not have been possible without the support of my colleagues and peers at the county of San Diego, Health \& Human Service Agency, Mental Health Services. I thank all of you who traveled this road with me and gave me the space and time to pursue new learnings.

I am indebted to Gonzalo Lopez, Manager, Office of International Trade and Technology for the City of San Diego whose assistance was invaluable, as he is the memory of the BPCC and the soul of the BPCC.

To my dissertation committee, Dr. Mary Abascal-Hildebrand, Dr. Daniel Wolf, and Dr. Frank Medeiros for their expertise, guidance and valuable suggestions.

Iastly, I thank the membership of the Binational Planning and Coordination Committee for their participation, contribution and their courage to voice their thoughts and opinions. Your contributions and work have laid the foundation for the future agenda of the San Diego-Tijuana region. 


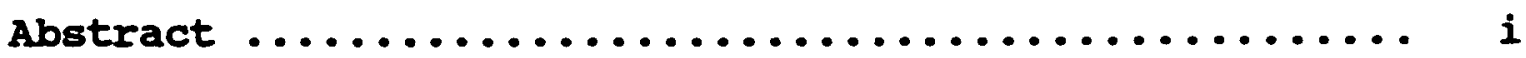

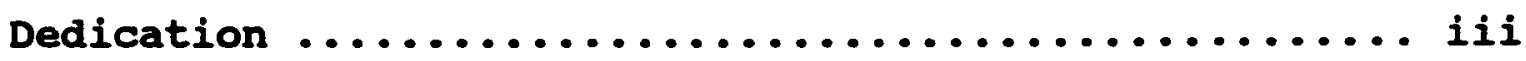

Acknowledgements....................... iv

Table of Contents $\ldots \ldots \ldots \ldots \ldots \ldots \ldots \ldots \ldots \ldots \ldots \ldots$ v

CHAPTER ONE: STATEMENT OF THE ISSUE........... 1

Introduction $\ldots \ldots \ldots \ldots \ldots \ldots \ldots \ldots \ldots \ldots \ldots \ldots \ldots$

Statement of the Issue $\ldots \ldots \ldots \ldots \ldots \ldots \ldots \ldots \ldots \ldots, 2$

Background of the Issue $\ldots \ldots \ldots \ldots \ldots \ldots \ldots \ldots \ldots \ldots$

Purpose $\ldots \ldots \ldots \ldots \ldots \ldots \ldots \ldots \ldots \ldots \ldots \ldots \ldots$.

Limitation of the study................... 10

Definition of Terms $\ldots \ldots \ldots \ldots \ldots \ldots \ldots \ldots \ldots \ldots$

CHAPTER THO: REVIEW OF THE LITERATURE $\ldots \ldots \ldots \ldots \ldots \ldots 12$

Introduction $\ldots \ldots \ldots \ldots \ldots \ldots \ldots \ldots \ldots \ldots \ldots \ldots \ldots \ldots$

Background of the San Diego-Tijuana Region ......... 14

Territorial Boundaries and Globalization ......... 19

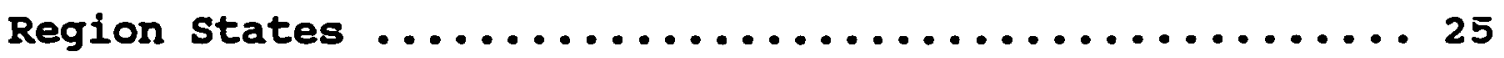

U.s. - Mexico Relations.................... 26

Transborder Relations in the San Diego-Tijuana Region..30 Government Structures in Mexico and the United States..33 Organizational Frameworks $\ldots \ldots \ldots \ldots \ldots \ldots \ldots \ldots \ldots$ Local Transborder Institutional structures.........46 Critical summary $\ldots \ldots \ldots \ldots \ldots \ldots \ldots \ldots \ldots \ldots \ldots \ldots$ 
CHAPTER THREE: RESEARCH DESIGN AND METHODOLOGY ..... 52

Introduction $\ldots \ldots \ldots \ldots \ldots \ldots \ldots \ldots \ldots \ldots \ldots \ldots \ldots \ldots \ldots \ldots \ldots \ldots$

Theoretical Framework of Methodology ............ 53

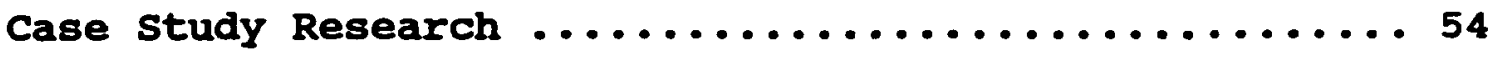

Research Design ........................... 56

The Interviews $\ldots \ldots \ldots \ldots \ldots \ldots \ldots \ldots \ldots \ldots \ldots$

General BPCC Meetings .................... 59

Archival Record Review ................. 59

Entry to Population ..................... 60

selection of subjects ................... 61

Data Analysis ......................... 63

Critical summary ...................... 66

CHAPTER FOUR: FINDINGS AND ANALYSIS ........... 67

Introduction $\ldots \ldots \ldots \ldots \ldots \ldots \ldots \ldots \ldots \ldots \ldots \ldots \ldots \ldots \ldots \ldots \ldots \ldots$

Regional Context ......................... 69

Tne Need for a New Agenda .................... 70

Intended structure of the BPCC ............. 70

Actual Form and Function of the BPCC structure .. 73

Decision Making Process .................. 76

Maintaining or Developing a New Entity ........ 80

The Need for Economic strategies ............... 84

Strategic Planning for the Transborder Region ... 84

Difference Between Strategy and strategic Plan .. 88

The Need for Collaboration ................... 90

Transborder Collaborative Leadership ......... 90

$\mathbf{v i}$ 
CHAPTER FIVE: FINDINGS AND RECOMMENDAMIONS ........ 97

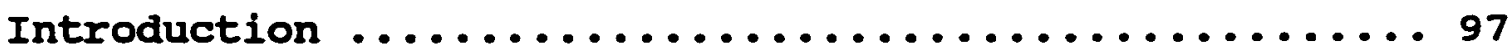

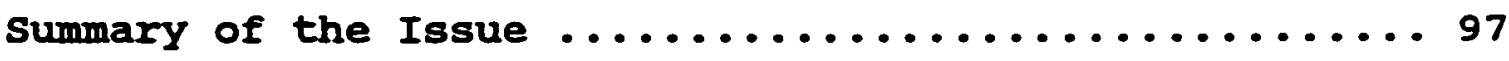

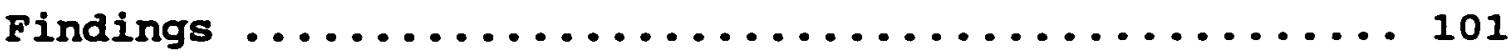

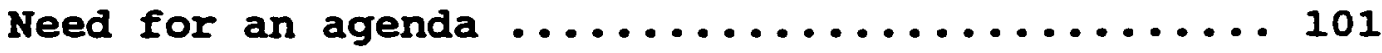

Need for economic strategies .............. 106

Need for collaboration ................... 108

RECOMMENDATIONS............................. 109

REFERENCES..............................113

APPENDICES................................ 125

APPENDIX A: Letter of Agreement between San Diego 125 nd Tijuana

APPENDIX B: Map of U.S.-Mexico Border Region ... 129

APPENDIX C: List on Interviewee Questions ..... 130

APPENDIX D: Letter to BPCC Coordinators ....... 132

APPENDIX E: Letter of Approval from Coordinators 136

APPENDIX F: Introduction to Co-chairs ........ 139

APPENDIX G: Informed Consent ............... 143

APPENDIX H: Ratification of Letter of Agreement. 145

APPENDIX I: Manager's Report, Report No. 97-110. 150 June 25, 1997

vii 
CHAPTER ONE

STATEMENT OF THE ISSUE

"Economics, not politics, defines the landscape on which all else must operate" (Kenichi Ohmae, pp. 119-125, Harvard Business Review).

\section{Introduction}

It is becoming more and more apparent that we need to think about how we might live in a borderless world. Linked through a sophisticated communication system that instantaneously provides us with the latest information on consumer goods, the importance of where these goods came from and the role governments and national boundaries play become less and less important. Kenichi Ohmae (1990) points out that the development of an economic base no longer lies within countries but between and among regions and cities. Nation states are increasingly losing their role and footing in the global economy of today's border less world.

Thus in economic terms, if one treats the United States, (U.S.) or Mexico as single economic entities or units of analysis it is to operate on the basis of implausibilities, fiction and averages. Ohmae affirms that what does make sense is the territorial divides of region states such as San Diego-Tijuana; the Silicon Valley-Bay 
Area; Baden-Wurtemberg in the upper region of the Rhine: the Lanquedoc-Roussillon region, centered on Toulouse; the Growth Triangle of Singapore; Johore and neighboring Riau Islands of Indonesia; and Osaka and the Kansai region among others (Ohmae, 1995).

These geographical units are natural economic zones harnessing a combination of essential resources, allowing their participation in the global economy. These resources include infrastructure of communications, transportation and professional services. These region-states are economic units that welcome foreign investment. Some of their assets includes their ability to tap diversity, their participation in global markets, the focus to improve the quality of people's lives, productive employment and they have greater access to the best and cheapest products from anywhere in the world.

\section{Statement of the Issue}

There is a growing concern over the lack of a transborder strategy on sustainable economic development of the San Diego-Tijuana region (Clement \& Zepeda 1993). The absence of a strategy poses a challenge on future economic development and integration of the region in light of the functional interdependence of the two cities, the North American Free Trade Agreement (NAFTA), and the developing 
markets of the Pacific Rim and Latin America. Without a regional strategic plan, the ability to gain economic prosperity and improve the quality of living standards for the region is diminished.

A region-state planning framework would facilitate the management of sustainable economic development in the border region and provide a vision for economic integration. This planning effort would need to be developmental in nature, which would require a partnership between multiple players from the public and private sector.

Furthermore, there is a perceived need in the region to establish a binational entity that can have oversight and a broad range of powers, as well as the ability to make recommendations on policy directions to the two local administrative governments on sustainable economic development (Report of the Binational Task Force on Economic Development and Transportation Infrastructure, September 30, 1993).

Moreover, at present, there is a plethora of local efforts; that need to be integrated to foster joint action and consensus-building in the region. Initiatives from the San Diego World Trade Center (established by the City of San Diego and the San Diego Unified Port District), the San 
Diego Dialogue Consortium, the Chamber of Commerce International Division, the City of San Diego Economic Development Corporation, and the San Diego Association of Governments (SANDAG) are efforts towards the economic development of the region. Other independent efforts include partnerships with academic, nongovernmental entities and private firms that evaluate, assess and participate collaboratively in the restructuring of the economy and the improvement of quality of life (QOL), on both sides of the border.

State and federal entities as part of their mandate in the United States and in Mexico are also involved in the border region. The International Boundary and Water Commission (IBWC), established in 1889 has a U.S. and a Mexican section, each reporting to its foreign relations department. The IBWC closely cooperates and interacts with local and state governments on maintaining the boundary, dividing the waters of international rivers according to treaty obligations, flood control and sanitation activities (Ganster, 1993). Other national offices include the U.S.Mexico Border Affairs Office, which coordinates relations between U.S. agencies and their counterparts in Mexico, and the Environmental Protection Agency which administers border environmental projects. Additionally consultative 
mechanisms and binational institutional arrangements exist, and will be referenced in Chapter 2 in more detail.

Given these facts and institutions a regional strategy for sustainable economic development may necessitate a regional entity that would bring together multiple stakeholders and serve as a cataiyst to generate common and coherent regional strategies for the range of issues that face the twin cities.

An initial step was taken in 1993 by establishing a cooperative agreement between the City of San Diego and the municipality of Tijuana, manifested in a Letter of Agreement. The Letter of Agreement in the area of binational planning and coordination unites the two cities to work on common issues affecting their joint border (see Appendix A). The two cities agreed to cooperate in 11 core areas:

I. Municipal and Regional planning

II. Economic Development

III. Police Services

IV. Fire Services

v. Water and Sewage Systems

VI. Library

VII. Parks and Recreation

VIII. Technology Transfer 
IX. Waste Disposal and Recycling

X. Environmental Protection

XI. Emergency Management

Pursuant to the Letter of Agreement the Binational Planning and Coordination Committee, (BPCC) was established in 1993 to take on responsibility for the general

management of programs and projects undertaken pursuant to the Agreement. Although the BPCC is not a formal advisory committee to the governmental entities of San Diego and Tijuana, and has no formal decision making powers, no oversight or monitoring functions, and no policy making authority in the border area, it nevertheless provides the coordination of joint transborder projects and is responsible for the general management of programs and projects undertaken pursuant to the Letter of Agreement. Background of the Issue

Although the last two decades had brought prosperity and economic diversity for these twin cities, each city is faced with special problems in the 1990s. At the present time, San Diego is recovering from the economic recession that had its onset in 1990, consistent with the national recession, the downsizing of defense related industries, and the financial restructuring that has been occurring due to the over-spending that characterized the 1980 s. 
For Tijuana, the recent financial crisis of 1994, the high population growth rate (approximately 5 percent per year), deficient infrastructure, the decrease of the of living standards, and limited growth in per capita income stagnates the Tijuana economy as well. This disparity between the level of economic activity and per-capita income, the limited availability of public services, the underdeveloped physical infrastructure of the city, and high rates of population growth, present challenges to Tijuana's future economic expansion. This period has been characterized by Clement \& Zepeda (1993) as a crisis necessitating transborder strategies to solve the aforementioned problems in the region.

The challenge for the BPCC and the region, then, is to develop sustainable economic development strategies for the region and an entity or structure that brings the regional context of bilateral relations to a different level of cooperation and integration beyond a free trade zone. Learning more about the BPCC members views on the issues, might enable the region to take the next step toward actively planning for the region's future.

Transboundary economic planning in the region for the Mexican side is mainly the responsibility of its federal and state government. For San Diego the key decision- 
making structures are locally based, with ties to the U.S., state and federal government. Matters such as border crossing facilities, water pollution, and the development of border crossings are dealt with at the federal level. Herzog (1990) indicates that most border problems are resolved on an ad-hoc basis, with an absence of cross border communication and joint planning. Informal dialogue and negotiation, however, led to cooperative ventures on boundary issues such as pollution control, crime, disaster response, and traffic management (Sloan \& West, 1976). Despite these forms of cross-border dialogue, the enormous polarization between the United States and Mexico still makes transborder cooperation difficult at best. Given these dimensions, what are the transborder issues that will influence economic development in this region? Gerber, 1993 analysis of the issues, indicates that low productivity, low value added jobs, a less skilled workforce, and the low per capita income of the population contributes to the stagnation of economic growth and prosperity for the region. Gerber also adds that industrial and urban infrastructure deficits and environmental concerns further contributes to the local issues and concerns. Clement and Zepeda (1993) point to the perceived need to restructure the region and its 
economies. The impetus for this perceived need lies not only with the global context of competitive markets, but in the problems impacting the two economies. The restructuring of the transborder economic region is necessary to develop a diversified economic base for San Diego and Tijuana, so the region can attract internationally-oriented business opportunities to the area and increase its competitiveness in the world market. Furthermore, restructuring efforts are needed to stimulate the depressed local economies, create higher priority jobs and quality infrastructure, improve the quality of life, and develop long-term economic prosperity. Moreover, the functional interdependence of the region can no longer be neglected, as it is vital for social and economic transborder development as the region moves into the 21 st century and face the challenges of globalization and world markets.

\section{Purpose}

This research study proposes a single case-study approach to analyze the BPCC using a qualitative methodology to study the BPCC. This case-study seeks to understand the role and functions of this entity with respect to its form, its structure and its collaborative and cooperative leadership relationships in the border 
region. Furthermore, the study explores with the partnership of the BPCC the need to develop sustainable economic development strategies for the region as well as the need to maintain the same organizational structure, or develop a separate entity that would have a broad range of powers. It is important to note that there is no strategic plan for this region at present and no one entity that is managing the transborder issues of the region.

\section{Limitations of the study}

Since the BPCC is the only formal entity established by the government administrations of San Diego and Tijuana to enhance cooperation and coordinate projects and programs, the focus of the study is limited to the BPCC, collaborative processes in the border region of San Diego and Tijuana.

In using a qualitative methodology to study the phenomenon of a transborder entity, the following limitations should be noted. This study is interpretative and descriptive in nature so it does not propose generalizations about its findings. The analysis of findings are based on subjective social phenomena that cannot be controlled or replicated by others for observation. In addition, this study is interpretative and descriptive in nature, therefore it does not attempt to 
imply cause and effect relationships.

Definition of Terms

Regional Development - Locally-based, economic, environmental and socially planned development.

Region-State - Geographical natural economic zones. They may or may not fall within the borders of a particular nation.

Economic Integration - Namely a free trade area, a customs union, a common market, economic and monetary union and or total economic integration (Laffan, 1992).

Sustainable Economic Development - An economic

development strategy that seeks to meet the needs and aspirations of the present without compromising the ability to meet those of the future (World Commission on Environment and Development 1987:40).

Municipality - A local level of government, similar to City government. The municipality of Tijuana has a Presidente Municipal.

Quality of Life - The concept includes social conditions, including progress, well-being, development, general welfare, the good life, the just society (Harland, 1971). It is the integration of the economy with the social and physical environment (Calavita, 1993). 
CHAPTER TWO

Review of the Iiterature

\begin{abstract}
"It goes without saying that, in the contemporary world, no "sovereign" state can act in isolation from or in disregard of other states without inflicting considerable damage on itself. The "impermeability" that characterized the classical model of the sovereign state is being widely challenged." ( Yoshikazu, Sakamoto, pp. 1-14, 1994).
\end{abstract}

\title{
Introduction
}

The world economy is a complex matrix of interrelationships between multinational firms and nation states transcending delineated boundaries. The economic world system is thus linked to powerful banks and transnational corporations (TNC), that are highly centralized in the industrial nations of the world. The introduction of the International Monetary Fund (IMF), the World Bank, and the General Agreement on Tariffs and Trade (GATT) signed in 1947 are some of the entities that form what has been termed the International Monetary System. The increase of functional interdependence of transborder regions has been of interest to European scholars. Some have focused on the transborder economic impact of activities on either side of the boundary (Sayer, 1982); others have studied the legal and political implications of transfrontier cooperation (Anderson, 1982; Dupuy, 1982; Hansen, 1983; Strassoldo, 1982). Still others 
have examined transborder regions as functional planning regions (Strassoldo, 1982). The Council of Europe and the ECC in the 1970 s sought to establish an applied research agenda on the nature of border regional problems. Additionally, they explore solutions to these problems through multilateral cooperative agreements (Council of Europe, 1977) .

This chapter presents an overview of the historical perspectives of nation-state boundaries, globalization, the development of region-states, and how international boundaries become increasingly diffuse in the global market of the twenty-first century. The twenty-first century brings the development of region-states, territorial divides that form natural economic zones, often small in geographical size yet mammoth in their economic output. Ohmae Kenichi (1990) argues that in a borderless world, regions such as the Kansai region-Osaka, Kobo and Kyoto have a cumulative GNP comparable to the sixth-largest nation state just after the United kingdom.

These regional transborder economic collaborative efforts have been formal and informal in light of the interests and problems that affect border regions. Linkages are forged in concerted efforts, some institutionalized and sanctioned formally, other efforts limited in depth, scope and substance. Barriers that stem from governmental structures, the political climate of a 
region, the economic development of a region, and cultural and linguistic differences of a region contribute to the challenge.

A review of the research literature on the aforementioned, on collaborative leadership relationships and on organizational perspectives will be presented as a tool to understanding and analyzing institutional structures such as the BPCC. This review will provide a nexus and a practical context for understanding the modus operandi of the BPCC as well as providing insights on the future direction of the San Diego-Tijuana transborder region. This chapter concludes with a summary of the transborder institutional structures established in the San Diego-Tijuana region.

Background of the San Diego-Tijuana Region

The San Diego-Tijuana border is a region that lies within the international boundary line of the United States and Mexico, located at the far west side of a 2,000 mile long border that encompasses what Jamail \& Gutierrez (1992) named the U.S.-Mexico borderlands. This area stretches from the Gulf of Mexico to the Pacific Ocean, (see Appendix B). This boundary zone has marked economic and social differences, however the San Diego-Tijuana region has been able to attract over the last fifty years people and industry to both sides of the border, creating an economic 
region that can capitalize on the opportunities that are shaping this economic zone.

Clearly the maquiladora industry in Baja California and along the San Diego-rijuana border has contributed enormously to the internalization of the region. Foreign firms, such as Asian companies have located in Tijuana, establishing Tijuana as the world premier television manufacturer. Consequently, business service firms specializing in transborder international business have grown, giving these firms the expertise to do business throughout the world. Other characteristics that establishes the San Diego-Tijuana region as a natural economic zone is San Diego's telecommunication and technology industry, its intellectual infrastructure, its emerging industrial clusters and its economic information and analytical systems (Lopez \& Clement, 1996).

Prior to the First World War, San Diego was an agricultural area like much of southern California. Defense operations grew in the 1920 s and the city's economy blossomed during the Second World War. Tijuana during this time was an area mainly uninhabited until urban development attracted tourism, horse racing, and dance halls, which became very popular when in the 1920s the U.S. passed the Eighteenth Amendment to the Constitution which prohibited 
alcohol consumption in the United STates. Substantial growth in population became evident in San Diego and Tijuana in the 1940 s when respectively, 280,000 and 22,000 people lived in the border region. By 1990 there were 2.5 million people in San Diego county and 747,000 people in Tijuana. If you include the municipalities of Ensenada, Mexicali and Tecate, a combined population of almost 2 million people live south of this border region. San Diego's population in 1990 was approximately 65 percent Anglo-Saxon and 25 percent Hispanic origin. Other ethnic groups in San Diego county include African-Americans, Asians or Pacific Islanders and Native-American and they comprise the remainder 10 percent (1990 Census of the Population) .

Economic activity in this border region has grown in leaps and bounds with the evolution of urban development (Herzog, 1986). Cities are the locus and impetus for economic change, the concentration of resources, development of technology, infrastructure and capital which is utilized in the maximization of a region's productive potential. This border region has a diverse economic base that includes commerce, trade, tourism, manufacturing plants, services, and research and development, creating a mutually interdependent economic zone. San Diego's largest 
export market is Mexico, with $\$ 1.8$ billion in merchandise sales recorded during 1993 out of $\$ 4.4$ billion of its international exports. Baja California exports in 1992 were approximately $\$ 452$ million.

San Diego's and Tijuana's functional interdependence has also created cross-border problems related to migratory and environmental conflicts, infrastructure deficiencies, border space issues, economic challenges, and the implementation of the North America Free Trade Agreement. Resolution of these problems requires a joint economic strategy that must be articulated from a regional perspective as well as from an international and domestic perspective.

Internationally, the development of the global economy has forced the process of restructuring the national and regional economies of both nations over the last twenty years. The move of the two nations towards privatization, corporate and governmental reorganization and the development of quality and cost-effective, efficient production has evolved in direct response to the increasing international competition of the world market. Other contributing factors include the end of the cold War, the development of the European Union, and the collapse of the Soviet Bloc. China's awakening and gradual entry into the 
world market, as well as the economic development of the Pacific Rim and the democratization of Latin America are additional dimensions that are forcing the restructuring of the two nations and the transborder region of San Diego and Tijuana.

Domestically, transborder problems have a long history and are grounded in linguistic and cross-cultural social dimensions (Dillman, 1969, Gildersleeve, 1978; House, 1982), the political economy of border urban space, the management of transborder problems, and the decision-making process across the boundary (Herzog, 1990). It is not surprising, then, that in the San Diego-Tijuana region polarization exists reinforcing the need for a collaborative transborder partnership that is institutionalized in a legitimized structure or entity. One that would take leadership on mutually agreed transborder issues. A strategy or strategies to address the multiple problems that confront this region would further facilitate the integration of the region into a major economic and metropolitan zone.

Furthermore, the cross-border relationship between San Diego and Tijuana has been developing amidst two distinct societies with diverse cultural backgrounds, languages and economic status of first nation and an emergent nation. 
These asymmetries present an additional challenge for the economic development and integration of the region.

\section{Territorial Boundaries and Globalization}

The concept of territorial boundaries dates back to Mesopotamian, Roman and medieval cities. These cities were encircled by fortress-like walls which served as protection and to divide kingdoms or empires (Taylor, 1985). The study of international political borders can be traced to the late nineteenth century. Friedrich Ratzel initiated the knowledge base on the subject of nation state boundaries and the political power that locational and spatial relationships establishes. Ratzel's views of the boundary illustrate the notion of "sovereignty." This concept can be traced back to Aristotle's work on the need to recognize the state as the supreme power, the ultimate source of authority, law and legitimate force within its boundaries (Kolinsky, 1981).

In the nineteenth century the notion of a nation-state was firmly grounded in nationalism and the state was defined as the supreme power, which guards the sovereignty and territorial integrity of the nation. Thus, boundaries became the negotiation point where important changes in political power would develop over the next century.

The concept of boundaries in the twentieth century provided functional lines of defense between countries during a period of territorial expansion and redefinition 
of the nation states. Military confrontation in the first part of the century characterized the acquisition of territory and jurisdiction. Scholars such as Spykman, (1942) studied the relationship between boundaries and national security; Boggs (1940) emphasized the strategic importance of boundaries; Jones (1945) wrote a comprehensive guide for decision makers in the area of boundary delineation, and Hansen (1981), states that the Mexican-U.S. border attracts migrants due to the economic opportunities of the border region.

In the latter part of the twentieth century the concept of international boundaries continued to change. Boundaries evolved in response to the development of global, economic, political, environmental and technological trends. The nation-state was the predominant form of political economic and legal organization. George Modelski (1972) suggests that globalization has multiple dimensions at a local, national, regional, and international level. Iinked through webs of networks, telecommunication systems and relationships, systemic interdependencies between these levels create economic and political interactions that impacts the global community. Thus, international politics become the bastion for political organization at the global level. The present crisis in Iraq, the ongoing turmoil in Northern Ireland, and the reconstruction of Eastern Europe are examples of 
situations that are socialized and politicized through the interplay of multilateral diplomacy and international sanctions from the global community.

From an economic perspective, Hirst \& Thompson (1996)

argue that the international economy is centered around three major economic powers, the Triad of Europe, Japan and North America. The G3 exert powerful governance over financial markets and economic trends, thus demonstrating that globalization is a myth. Instead, it is concentrated among the most advanced industrial economies, and an international economy best describes economic expansion driven by transnational companies (TNC), who do not have allegiance to a particular nation-state.

The globalization of economic activity had its roots in the post World War II period when, a united Europe faced the task of economic, political and social reconstruction. There, a variety of groups embarked in the development of several entities that would change the world. The European Economic Community (ECC) was established in 1958; its main objective was the establishment of a common market with broad economic policies. The ECC, presently known as the European Union (EU), has an institutional structure and policy-making authority in a common market with the goal of economic and monetary union in the twenty first century. This Single European Market created in 1992 is a unified economy with a strong regional trading block in the global 
market. The EU has been a 40 year experiment that continues to evolve and develop.

The Council of Europe is another group that promotes intergovernmental cooperation in policy areas such as: human rights and legal matters, social and public health policy, mass media, education, and culture, conservation, and the environment and youth affairs. standing conventions and conferences facilitate public policy making and social exchange in Western Europe. Specialized conference of ministers meet annually to provide government officials and politicians a forum to discuss regional planning, environmental protection, town planning and local democracy. Similarly, the Binational Planning and Coordination Committee (BPCC) in the San Diego-Tijuana region jointly address some of the same issues through their cooperative agreement. However, by its own design the BPCC is not a policy making entity, therefore, the BPCC is limited in its degree of influence in the region and has no advisory capacity to the administrations of the two cities.

The European Free Trade Association (EFTA), involving the countries of Austria, Britain, Denmark, Norway, Portugal, Sweden and Switzerland, represents another case example. Theirs is an intergovernmental approach to economic integration and free trade zone expansion within an institutional structure. It was designed to allow 
member states to benefit from free trade without sacrificing national sovereignty. Its range is limited to sectoral cooperation over a wide range of policies and does not engage in advanced forms of economic integration.

These entities operate international credit systems and finance relocation of industries all over the world. These and other developments create structures and mechanisms for dialogue, collaborative ventures, partnerships, alliances and unions. They also institute formal transburder and transnational agreements, strategies and policies in a diversity of areas linking diverse economies, people and interests to create opportunities to maximize their potential in the international and global market.

Holmberg and Sandbrook (1992), present another factor that is salient in the global economy: the recognition of the interdependence between the ecosystem and the forms of production. Intimately tied to each other, the relationship between the preservation of the environment and economic development involves trade-offs. These trade-offs cover a gamut of biological, economic, and social systems, making sustainable development a reality. Such reality has the interest of the greater whole with no presuppositions to boundaries.

In the End of the Nation State, Ohmae (1995), argues that in a borderless world, boundaries are delineated by 
what he calls the 4 "I's" of business units. He states that the flow of investments knows no boundaries and no longer is geographically contained in nation states. Industries at the multinational level no longer depend on the state for their development. On the contrary industries are moved by market opportunities and resource availability. Information technology now makes it possible for a company to simultaneously operate anywhere in the world with a network capability to control and manage production through work stations without having a corporate office in every nation. The last "I" is represented by the individual consumer who has unlimited choices of the best products at the least cost through a marketing system supported by a web of information. Taken together the four I's make it viable to develop global markets without the support or intervention of nation states.

Ohmae's "4 I's" have been evolving in the San DiegoTijuana region over the last thirty years. Investment in the maquiladora industry by multinational and domestic companies is one example of businesses transcending borders. San Diego's telecommunication industry and sophistication facilitates commercial opportunities and reinforces the region's competitive advantage. Furthermore, San Diego also has more personal computer users than any other country in the world, giving unlimited access to consumers to the best quality products and the 
cheapest products from anywhere in the world (Lopez \& clement 1996). These developments are fortuitous in a region that requires sustainable economic development strategies in order for the region to be competetive in the world market.

\section{Region states}

The notion of globalization reveals strong regional patterns of development, from Latin America, to Asia, to the Soviet Block and to Eastern Europe. Regionalization is now widely recognized and increasing in importance in an international economic environment.

In The Borderless World, Kenechi Ohmae (1990)argues that as the interlinked economies develops, regional and city-level interests play a major role in a pluralistic world market. This development fundamentally changes the equation of market economies in the world. Region-states are economic areas that lie within the borders of nation states that lend themselves as port of entry to the global economy. These economic centers have a finite population of no fewer than two miliion and no more than ten to twenty million. They are autonomous and interdependent networks driven by private capital and a common interest in regional prosperity and sustainable economic development. They have a diversified flexible production, a regional governance, and a local financial sector.

These regions can weather much easier the impact of 
volatile trading markets by anticipating and responding to change quickly and according to market demand (Hettne, 1994). Such regions include the Kansai region-Osaka, Kobo and Kyoto, the Cascadia Region in the Pacific Northwest of the United States and Canada and the Regio Basiliensis in the Alsace-Baden-Basel region. At the heart of the regionalization phenomenon lies the information age shaping the flows of economic activity, consumer tastes and, choice.

The advantages the San Diego-Tijuana region possesses lies in its expextise on transborder operations, in establishing internationally-oriented business service firms, in high tech and industrial complimentarities, and in its potential to become a gateway city to Latin America and the Pacific Rim.

\section{U.S. - Mexico Relations}

Transfrontier cooperation between the U.S. and Mexico stretch across a 2,000 mile border from the Gulf of Mexico to the Pacific Ocean. This border region is beset with economic disparities, creating major socio-economic differences that contribute to the difficulty in planning efforts along the border and in metropolitan areas. Border cities such as Brownsville-Matamoros, Laredo-Nuevo Laredo, El Paso-Ciudad Juarez and San Diego-Tijuana have glaring economic disparities. Per capita income in U.S. border states is between five and seven times greater than in 
neighboring Mexican states. This economic asymmetry contributes to the tenuous development of border cooperation programs (Hansen, 1985). U.S.-Mexico relations historically have been manifested with conflict and lack of cooperation. The 19th and 20 th century was besieged with wars, loss of territory for the Mexican side, U.S. intervention in the political affairs of Mexico and the occupation of Veracruz by the U.S. in 1914. Furthermore, the expulsion of 300 thousand Mexican immigrants at the onset of the 1929 Depression in the U.S. and the Mexican expropriation of foreign oil firms in 1938 due to conflicts surrounding ownership of subsoil resources, characterized the relationship between the two countries in the early part of the 20th century (Ojeda, 1983).

Cooperation began to improve as a result of WWII. During this period bilateral agreements such as the Bracero Program was instituted to ease the shortage of man power created in the U.S. as a result of the war. The Bracero Program were terminated unilaterally in 1961 by the U.S. and a new Border Industrialization Program (BIP), which developed the maquiladora industry mainly in the northern border region of Mexico, was implemented by Mexico in 1965, to create new labor opportunities in response to the ones lost with the termination of the Bracero Program (Carrillo \& Hernandez, 1985). Other objectives of the BIP included 
the reduction of deficits in the balance of payments by promoting exports; the use of Mexican industrial capacity by using Mexican raw materials and components; foreign investment, and the improvement of the quality of life and skills in the transfer of technology.

Another major impetus for instituting the maquiladora industry was the real and perceived advantage of an offshore assembly program and the interest of developed nations to re-locate industries that were labor intensive in less costly emerging nations. Foreign and domestic firms expanded rapidly with positive returns in investments due to the steady growth of the Mexican economy. However, by 1970 the Mexican economy slowed significantly due to a government finance crisis, creating in 1976 the first major peso devaluation.

As the Mexican economy plunged into recession following the excessive spending of the late 1970 s and early 1980s, the Mexican government made the critical decision to exploit oil and gas resources. In an accelerated pace, Mexico increased its exports and opened the economy to foreign competition, forcing manufacturing firms or maquiladoras in Mexico to diversify their operations. At the same time, the stage for the next financial crisis of 1982 was being set due to an overvalued peso, and an overall inefficient economic policy. The 1982 debt crisis devalued the peso once again, reduced Mexican 
labor wages in half, and made the border region a extremely competitive, low-wage area by global standards.

The maquiladora industry boomed in the next decade. By 1991 the annual inflation rate of 160 percent was reduced to less than 20 percent, maximum tariffs were reduced from 100 percent to 20 percent and state-owned companies were reduced from 1,200 to 240 at the beginning of 1992. Other transformations have occurred such as the deregulation of financial markets and domestic economic institutions, reduced restrictions on foreign investment, and the diversification of the Mexican economy, making oil no longer the sole source of export earnings (Fry, 1992). U.S. exports to Mexico doubled between 1986 and 1990 and Mexico has become the third-largest trading partner after Canada and Japan.

It is against this backdrop that the North American Free Trade Agreement (NAFTA) was negotiated by U.S. President George Bush and President Carlos Salinas de Gortari of Mexico in early 1990. In 1993 the U.S. and Mexico entered into a trilateral agreement with Canada by signing the NAFTA. The NAFTA is an agreement to form a free trade region and it is not a European-style political union. The benefits of the NAFTA remain to be seen in the shadow of the third financial crisis of Mexico in 1994 and the $\$ 13.5$ billion U.S. bailout, which was fully repaid by early 1997 (Bosworth, Collins \& Lustig, 1997). 
Furthermore, the implementation of the NAFTA has had its difficulties independently of the 1994 crisis. Conflicts over sovereignty threatens the economic integration of the region, the unemployment and lay-off of U.S. low-skilled workers is blamed on the NAFTA, trade disputes and infrastructure problems has limit the potential of the NAFTA and the on-going anti-Mexican sentiment has contributed to the recurrent impasse facing the NAFTA. The binational agenda for the 21 st century for U.S. and Mexico will continue to have on the table beyond economics, issues on immigration, labor, environment and drug trafficking.

It is within this turbulent context that U.S.-Mexico and San Diego-Tijuana relationships unfold. In the next section I introduce the San Diego-Tijuana transborder collaboration and set the context in which the 3 inational Planning and Coordination Committee operates.

Transborder Relations in the San Diego/Tijuana Region Boundary regions, such as the San Diego and Tijuana free trade zone, have increasingly become a point of interest for United States and Mexico relations. Not only is this transborder zone the busiest in the world, it has nearly 3 million inhabitants. It is also a strategic location for economic activities such as assembly plants (maquiladoras), the implementation of the NAFTA, tourism, services, commerce, and research and development (Herzog, 
1990). In addition, substantial differences in culture, language, levels of economic development, migratory conflicts and distinct environmental and border space issues result in cumulative effects creating a most challenging dilemma.

The birth of the San Diego-Tijuana transborder region dates back to 1848 with the signing of the Treaty of Guadalupe Hidalgo. At the time the boundary was an artificial line cutting through an ecological zone. Its transformation began in the middle of the twentieth century with the gradual urbanization and development on both sides of the border. Treaties and binational agreements on transborder issues were mainly initiated at the federal and state levels of both nations. For example, the governments outlined agreements in 1944 on the utilization and management of waters from the colorado, Rio Grande and Tijuana rivers. In 1970, the agreement on Economic and Technical cooperation designated officials to maintain contact in matters of economic and social development of the border area. In 1978, the Environmental Cooperation Agreement launched a collaborative relationship on environmental issues and other transboundary problems (Bevans, 1972).

Economic linkages gradually evolved between the two regions, with exchanges in goods, services, people, workers, technology and capital. The integration of the 
two economies has been prosperous, albeit unequally so. In spite of all the U.S. rhetoric about immigration control, anti-Mexican sentiment and national sovereignty concerns, the interdependence of the two regions is of critical importance to both. This inter-dependence is contingent on two important factors: the migration of undocumented workers to the U.S. borderlands and U.S. access to cheap Mexican labor in Mexico. The first permits U.S. capital to benefit from cheap Mexican labor and the second allows U.S. firms to manufacture low cost products in the maquiladora industry (Reynolds, 1984).

Given the evolution of transborder interdependence, an array of formal institutional and informal responses evolved in the 1970s. For example, in 1976 public officials and bureaucrats sponsored a bicentennial conference series called the "Fronteras Project." This forum brought together public and private officials from both sides of the border to describe the common problems and opportunities of the Tijuana-San Diego region (Fronteras, 1976). Furthermore, a study commissioned by the state of California and the U.S. Department of Commerce (1978) was conducted to shed some light on how U.S. economic opportunities are tied to Baja California.

Another example of interaction between local government officials (city and county) was the decision to declare the otay Mesa an economic development district. 
officials foresaw the opportunity for international economic development in spite of the problems and the differences that exited. Similarly, the construction of a second border crossing at otay Mesa is a recognition of the mutual interests of the two cities (Comprehensive Planning Organization, 1978).

On the Mexican side, the federal government in Mexico City invested in the development of tourism, retail trade and infrastructure in the 1970s. These projects included a tourist complex, the Twin Towers project, the new Cultural Complex, a $\$ 200$ million industrial park on the Mesa de otay and the Plaza Rio Tijuana shopping center (Chavira, 1982). Government Structures in Mexico and the United States

Despite these efforts and the many shared interests, the decision-making processes of these two countries are bifurcated along national boundaries. Herzog (1986), indicates that at a meeting of public officials from both sides of the border, U.S. officials unanimously rejected a proposal to create a joint San Diego-Tijuana Planning Commission, echoing that it was unrealistic and ahead of its time. To understand political decisions on both sides of the border. I present below a brief examination of the decision making processes and policy making of the U.S. and Mexico.

There are several structural features in the Mexican political system that create barriers in the local 
political process. To begin, there are certain elements that are a given in the Mexican government: a tightly centralized political structure governed by a one-party system (Ward, 1986), the absolute power of the presidency (Grayson, 1995); elite bargaining arrangements (Purcell, 1975); and the "sexenio" or six year presidential term of office around which virtually all Mexican political decisions revolved around. Thus, local government is limited as an agency of policy making since the power is with elites at the federal level and, to a lesser extent, at the state level. Jimenez etal. (1994) note that the states have residual powers and are largely dependent on the federation. They are prohibited from creating alliances or treaties with other states or countries. Federal funding for regional development is channeled through the state to achieve national economic goals and policy priorities.

From Mexico the structure of the government in the United states appears baffling at best. With an array of jurisdictional levels that include federal, state, county, city and single-purpose agencies it is hard to discern who is coordinating what. However, these structures have a degree of independence and authority, albeit limited that is unknown to Mexico. Nevertheless, local governments cannot conduct foreign policy or deal with national security issues, much like their Mexican counterparts, 
though the issues they can become involved are in the area of economic, social and cultural interchanges.

It would appear, then, that transborder economic planning for the San Diego-Tijuana region necessitates different levels of government strategies and intervention from the two countries. From the perspective of Mexico, transborder economic and policy decision making processes would have to be supported and sanctioned by the federal government. On the other hand, since it appears that in the United States decision making and policy making favor local government, it is plausible that San Diego's local policy makers in collaboration with Tijuana and appropriate levels of government can develop a comprehensive transborder economic strategy for the regions. However, without a legitimized institutional structure, regional strategies and implementation of regional policies would be less feasible.

In the next section I explore organizational research and present specific frames or perspectives from which to interpret organizational structures such as the BPCC. It is important to analyze the BPCC from multiple organizational lenses to understand and gain insights into viable structures and strategies that can be considered and utilized in binational and cross-border organizations.

\section{Organizational Frameworks}

The organizational data suggest that frames or 
perspectives can be helpful in understanding and analyzing entities such as the BPCC. Organizational entities, whether long term or ad hoc, have goals, boundaries, levels of authority, communication systems, coordinating mechanisms, and distinctive cultures. Community leaders, politicians, public officials, coordinators, managers and individuals participating at different levels of an organization can use institutional or organizational models to increase their knowledge of how organizations are structured, how they function and how effective they are in accomplishing their mission. For the purpose of this research study I will be utilizing different organizational frames to analyze the findings.

Bolman and Deal (1984), describe four organizational perspectives or frames that are useful in understanding organizations and how the actors or players within function to accomplish the organization's mission and they are as follows: the structural frame, the human resource approach, the political approach and the symbolic frame.

The structural approach is fitting of organizations that are rational and exercise control through authority and coordinating functions. They work effectively in environments that are task-focused and predictable. Rules and standard operating procedures (SOP) govern conditions of work and relationships with the environment. They use vertical and lateral strategies to control the environment. 
Vertical strategies include those activities conducted by upper management through sop's. Lateral strategies are manifested when line staff coordinate with one another in meetings, work groups, task forces, and committees. At this level the coordinating functions can be informal or formal and negotiation and persuasion are the tactics most often used to problem-solve, make decisions and develop plans. Achieving a balance between role differentiation and integrating all the different aspects of activities are crucial task for this type of organization.

In the human resource approach, the organization focuses on the relationship between the individual and the organization. From this perspective the idea is that human resources are the most vital components of an organization and that a fit between the employees and the organization is essential so both can benefit and accomplish the organization goals and mission. Management strategies that support this approach include participatory management, job enrichment opportunities, and training and staff development. Influence rather than the exercise of authority is the method for enhancing collaboration in decision making.

The political approach, on the other hand, offers a view of the organization as political arenas made up of multiple actors who have multiple interests, and they coalesce to obtain scarce resources. Public sector 
organizations are a case example where constituencies play out their divergent interests and conflicts amidst a negotiating and bargaining process to accomplish goals and resolve conflicts. This frame suggests that power and self interest are motivating factors in the change process. The consumer movement, trade unions and other advocate groups are a prime example of the shift in power in the public and private sectors. The policy process, the establishment and the status quo are activcly contested in these political arenas. This frame differs from the structural and human resource model in that the political approach socializes the issues and the policy making process.

Lastly, the symbolic approach demonstrates how organizations are ambiguous, fluid and operate in uncertain environments. The locus of this approach centers on how events or situations are interpreted and how symbolism gives meaning to a chaotic situation. Rituals, myths, metaphors and humor are used to connote understanding, clarity and predictability. Symbolism provides a framework for power and its exercise, whether real or perceived. Each of these frames according to Bolman \& Deal (1984), present perspectives that can exist simultaneously in one organization. One approach or frame is not necessarily exclusive of another.

Berquist (1993), in contrast, uses order and chaos theory to examine organizational processes, and applies a 
postmodern critique perspective to four models of contemporary organizations. The "hybrid organization" is described as an organization that is often small to medium size, highly flexible and adaptable, has project teams or work groups, and has a highly diverse product focus. The structures of this type of organization are characterized by temporary systems and ad-hoc problem solving groups that are organized around problem solving rather than stratified functional groups. Emphasis is on flexible and dynamic ways of accomplishing the task. The "cyclical organization" is defined as going through developmental life cycles. The notion of cyclical change is embedded in environmental conditions and changes that are required to remain competitive, even when they require restructuring, reengineering and downsizing.

The "intersect organization" is a blending of organizations that have unclear boundaries, multiple governing bodies and diverse constituencies. Traditional rational decision making processes and linear problem solving are not useful in responding to changing public demands in this type of organization. Most intersect organizations are in the business of providing services which are primarily linked through communication. Negotiation and mediation skills build consensus in this case. This blending of public and private organizations stems from the recognition that public entities cannot meet 
the demands and needs of society. Thus, collaborative partnerships emerge in intersect organizations in order to improve efficiency and skills of personnel. Communication is the essential tool in consensus building, as well a communicating the vision and goals.

Finally, the "turbulent organization" functions amidst rapid and often chaotic change. Structural change is continuous and based on the changing environment of the market place, causing the organization to change its modus operandi from within in order to respond to the changing environment. Berquist suggests that every organizational structure goes through all four approaches depending on its evolutionary stage. Morgan (1986) demonstrates how an organization can be different things at the same time and uses metaphors to diagnose, analyze and shape the management and the design of the organization.

These efforts are construed within organizational structures whether they are governmental in nature such as the BPCC, on the one hand or non-governmental on the other hand. The entities that are governmental in nature, such as the Office of Binational Affairs, the Department of Transborder Affairs, SANDAG, and the BPCC, operate within the hierarchy of departments of the city administration structure of San Diego and the municipality of Tijuana. These structures have organization levels, such as the institutional level, the managerial level and the technical 
level. They have role differentiation, standard operating procedures, goals and coordinating functions. Authority is centralized at the institutional level dictated by policy and the citenzenry. Vertical and lateral coordination varies according to the task at hand. These entities also operate within political arenas and proximate-policy makers who exert great influence through informal and formal practices of consensus building (Lindbloom, 1968).

Academic institutions such as the University of California in San Diego, San Diego State University, University of San Diego and Colegio de la Frontera Norte among others are, according to Bolman \& Deal (1984), coalitions of interest groups with different purposes and resources all attempting to influence the decision-making process and the policy-making process within a context of divergent needs and preferences. The political frame best describes these structures.

On the other hand, the Chamber of commerce, the San Diego City Economic Development Corporation, the World Trade center and other private and quasi-private entities are best explained in terms of Berquist's (1993) postmodern intersect organization. These entities blend governmental mandates with private enterprise either by privatizing or working in collaboration with diverse governing boards. These intersect organizations use communication to negotiate the agenda. 
Leadership in the structural or rational organization model is concentrated in the top echelons of the institutional level of the organization. Policy directives are linear, hierarchical and authoritative. They have a unitary actor mentality and a top-down orientation. Leadership is positional and mechanistic in nature, captured in the idea that management is a process of rational planning, coordination and command and control (Morgan, 1986) .

On the other hand, leadership in the political or intersect organization is manifested in collaboration with multiple interest groups. There are informal and formal processes of coordination. Persuasion, bargaining and influence mold decision making, problem-solving and policy making. Compromise, consensus building and persuasion are cooperative strategies use to accomplish the goals (Lindbloom, 1968). The players are professionals, the political stratum and the citenzery. Power is shared and the relationships are reciprocal as they socialize the issues and the policy making process. Leadership from this frame is reconstructive and generative and seems to have dimensions that reinforce transforming change. Collaborative leadership relationships in the twenty first century will need to be carried out in our nations, communities, in our government and private institutions, and in our businesses. For most of us, leadership is an 
elusive concept both in theory and in practice. Scholars in different disciplines have attempted to explicate who the leaders are and the concept and the practice of leadership. Leadership has been described as stemming from personality traits, attributes, or characteristics that are individually possessed, (Gibb, 1968; Hollander \& Offerman, 1990); as leadership define within the context of a group (Fiedler, 1967), as the leader's behavior (Calder, 1977 institutionalized within a structure of an organization (Smirch \& Morgan, 1982), as interfactional leadership and a catalyst for change (Rosener, 1990; Astin \& Leland, 1991), as a political process which manages the public's problem solving (Heifetz \& Sinder, 1988) and as transformational leadership (Burns, 1978), embodied in a relational, collaborative relationship or partnership (Rost, 1992).

The research literature on decision making processes see organizations by and large as decision making systems, that control the agenda, issues, processes, and objectives in order to influence the outcome (Morgan, 1986) and which fragment, routinize and bind the decision-making process in order to manage it ( March and Simon, 1958). Bolman and Deal (1984) suggest four different approaches to decision making in managing organizations. In the structural approach, decision making is seen as authority based on 
rational processes that is consistent with the organization's purpose. The human resource organization perspective focuses on forms of influence that reinforce mutual purposes and collaboration in decision making. The political frame offers a differert perspective suggesting that decision making is an ongoing process of bargaining and negotiation between major interests groups. In the symbolic approach to organizations, decision making is perceived as on organizational process that is ritualistic, symbolic in nature and may or may not achieve an outcome. Bryson and Crosby (1992), on the other hand, describe decision making as a political act in networks of organizations where there is no one in charge, in contrast to the traditional, hierarchical bureaucracy where there is a unitary actor which engages in rational planning and decision making to accomplish the stated objectives. In the situation where no one is in charge, many organizations are partially responsible for coordinating actions and achieving objectives. These loosely-bound organizations must dwell in political, issue-oriented planning and decision making.

In a shared-power world this decision making model is advantageous for solving issues which are most often conflictual and not consensual by nature. The effective 
use of this model lends itself to adopting solutions that contribute to the public good.

In Hecksher and Donnelion (1994), Heckscher suggests that people in post-bureaucratic organizations affect decisions by the power of persuasion rather than by their ability to command. Persuasiveness is based in relationships of trust, mutual benefit and interdependence. This type of decision making is constructed around a set of principles and guiding mission that the ideal interactive organization possesses. It is interactive because it is not a one way communication or command organization, but rather a back-and-forth dialogue among multiple actors. This type of organizational structure relies on informed consensus rather than authority. The context is usually committees, task forces, project teams and problem-solving groups. The BPCC as an entity exists within two governmental structures, that of the City of San Diego and the municipality of Tijuana. As such, these governmental structures are hierchical and traditional in nature. They exercise authority through policy and their constituencies. They have role differentiation, rules, and standard operating procedures that guide the behavior of the organization. However, the BPCC operates informally within this framework through lateral forms of coordination and formally within the organizational structure of the two 
city administrations. The coordinating functions of the BPCC are characteristic of work groups and committees that are tasked with a specific function that exist within a variety of organizational structures such as the ones articulated by Bolman \& Deal (1984), and Berquist (1993) in their organizational frameworks.

Local Transborder Institutional structures

Concerted efforts have been made in San Diego to establish institutional structures and mechanisms to address transborder issues over the last ten years. Ganster (1993) states that Tijuana has become a region for economic opportunity and collaboration and has transformed its image away from being the source of San Diego's problems. For example, the San Diego Economic Development Corporation recruits firms to locate production in Tijuana in light of the positive economic impacts that a Tijuana location has on San Diego's economy.

In 1986, the city of San Diego established the Mayor's Office of Binational Affairs under the direction of the City Council of San Diego. The purpose of the department was to coordinate transborder issues, including economic development, tourism, disaster preparedness and border sanitation as well as joint city council meetings. However, under Maureen O'Connor, the then-Mayor of San Diego, this department became largely a protocol office with insignificant action on transborder issues. 
In 1987, the County of San Diego established the Department of Transborder Affairs. In the six years following its inception, the department was very active in collaborating with Mexican agencies on key transborder issues. This department produced a series of reports on the costs and benefits of undocumented immigrants in san Diego county, and on regional public health and border crossing alternatives, among other issues. Despite these efforts, the fiscal difficulties for the county and a change of leadership in the Board of supervisors contributed to the elimination of the department in 1993 (Ganster, 1993).

Academic institutions have also played a major role in the border region. The center for U.S.-Mexican studies at the University of California, San Diego (UCSD), the Institute for Regional studies of the Californias at San Diego State University, and the Colegio de la Frontera Norte (COLEF) all collaborate with transborder entities. Some of the areas of collaboration are manifested in joint projects in the business sector, in the academic arena, and in skill development and the transfer of knowledge. Most recently the Transborder Institute of the University of San Diego and the Universidad Autonoma de Baja California in Tijuana have joined the transborder efforts. San Diego Dialogue (SDD) is another entity working on transborder issues with an academic connection with UCSD. Since 1991 
SDD has developed linkages and a close working relationship with the border region. It has also develop expertise in the area of transborder affairs.

The San Diego Association of Governments (SANDAG) is a public agency formed by local governments in San Diego County. SANDAG works primarily on regional planning and coordination needs. Under its auspices a Border-Related Issues Task Force was established in 1989 to identify issues and recommend solutions to common problems in the transborder region. In 1990 the Task Force issued its report recommending that SANDAG establish the capacity to interact with Mexico and suggested the development of a special unit for this purpose. While SANDAG did not establish such a unit, it assigned a staff member to take the lead and several publications related to the border have been generated. In 1996, SANDAG established the Committee on Binational Regional opportunities (COBRO). This committee advises SANDAG on border-related planning activities, issues and actions. Another example is the Greater San Diego Chamber of Commerce. The chamber has embarked on efforts to develop collaborative relationships with their Mexican counterparts in Tijuana.

The most recent effort in developing a mechanism for increased collaboration between the two regions is the Letter of Agreement between the City of San Diego and the City of Tijuana, the subject of this study, signed in April 
of 1993 and ratified in the summer of 1997. Pursuant to the Letter of Agreement the two respective mayors, Hector Osuna Jaime and Susan Golding, agreed to establish a Binational planning and coordination committee (see Appendix B) - Chaired by the two mayors, the group was intended to enhance cooperation and facilitate the exchange of information on joint programs and projects.

Although these are notable attempts on the part of governmental and non-governmental entities, academics and private groups, in coalescing to develop greater transborder cooperation, the process is inherently fragmented and tentative at best. In part this is the result of a lack of leadership, the continuous influx of new participants in the political arena, and their limited understanding of transborder relations and issues. other circumstances that play a role are the absence of an institutional structure, the absence of a consorted strategy or strategies, local fiscal and economic difficulties, and changing U.S.-Mexican relations. AntiMexican sentiments at the national and local level, and the inherent asymmetries of a first-world nation and a developing nation are additional contributing factors to the present challenge.

\section{critical summary}

The development of the global economy suggests that national and regional economies have to restructure as a 
response to the increasing international competition of the world market. The functional interdependence of regionstates such as the San Diego-Tijuana region creates an economic zone that can capitalize and maximize on opportunities to be able to compete in the world market and improve the quality of life of its citizens.

Although, transborder relations in the San DiegoTijuana region have developed amidst existing asymmetries, the functional interdependence of the two is a reality that intrinsically links the two economies, in spite of the negative rhetoric of the two countries.

Given these dimensions an array of informal and formal responses have taken place to coordinate the collaborative efforts of the two cities. A plethora of local organizations, task forces, offices, work groups and committees have over the past ten years collaborated on key transborder issues. Yet, consorted unified strategies have lacked and not one entity oversees long-term planning strategies for the region. The BPCC is at present the only entity that has the specific function to coordinate joint projects in the region.

The challenge for the San Diego-Tijuana region lies in its ability to develop a future agenda that addresses sustainable economic development strategies for the region 
and simultaneously addresses the need for an overarching entity to lead this effort. 
CHAPTER THREE

METHODOLOGY

"Constructions represent the efforts of people to make sense out of their situations, out of the states of affairs in which they find themselves. They are interpretations based primarily on experience to - "see it with my own eyes" or to "hear it with my own ears" is the best evidence that anyone can muster to demonstrate to him or herself the validity of his or her own constructions. " (Guba \& Lincoln, p. 70, 1989)

\section{Introduction}

This section gives the reader an overview of the reasons why the single-case study methodology was chosen as the most relevant for exploring both the process and context of a group or entity such as the Binational Planning and Coordination Committee. A single-case study examines the form and structure of this entity, its role, function, and decision-making processes within the context of the BPCC mission and objectives.

Eurthermore, it investigates the need to maintain the structure as is or restructure the BPCC and/or develop a new transborder entity. In addition, the perception by some interest groups to develop transborder sustainable economic development strategies for the San Diego-Tijuana region as well as the development of a strategic plan is 
explored by using a single case-study, qualitative methodology.

\section{Theoretical Framework of Methodology}

Qualitative research is naturalistic in essence. It is an approach that seeks to understand the meaning of an experience, program or entity. That is, the meaning of multiple realities as a result of interactions and perceptions is explored. The exploration of reality is inductive in nature, it is flexible, evolving and emergent. There are no predetermined hypotheses, and there is no manipulation of variables. Merriam (1988) states "what one does do is observe, intuit, sense what is occurring in a natural settings-hence the term naturalistic inquiry" (1988, p 17).

There are other overarching characteristics of qualitative research that distinguished this methodology from traditional quantitative research methods. First, the qualitative researcher is concerned with process rather than outcomes i.e., the what, how, when and why of the phenomenon under study. A second feature is the exploration of meaning and how people construe their realities, how they experience the situation, how they interpret the situation and now they conceptualize the experience. The third feature is that the researcher is 
the instrument for data collection and analysis. The qualitative researcher interprets, draws inferences and makes initial impressions about the data. A fourth characteristic is that the research is conducted in the field. People, events, situations, programs, and institutions are studied in their natural settings (Merriam, 1988).

\section{Case Study Research}

Case study research is described under the rubric of qualitative or naturalistic research that is inductive, descriptive, and seeks to explain a phenomenon rather than prove or disprove it. This method of study is heuristic in nature; that is, new meanings, insights and understanding of the phenomenon under study can emerge and the result can be a rethinking of the subject matter (stake, 1981). It is particularistic in nature because the focus of study can be a situation, event, program or phenomenon (Shaw, 1978). It can be descriptive in that the case study illustrates the complexities of a situation through "thick" description of the phenomenon under study (Guba \& Lincoln, 1981). Case study is also depicted by other writers as a process that describes and analyzes some entity as it unfolds over a period of time (Wilson, 1979). Yin (1984) argues that a case study is designed to explore situations where it is 
impossible to separate the phenomenon's variables from their context.

There are certain philosophical assumptions and theoretical underpinnings of a case study that set the ground for case study methodology. In qualitative research the objective is to understand the meaning of an experience, recognizing that there are multiple realities which are highly subjective and need to be interpreted rather than measured. In this paradigm, there are no predetermined hypotheses or theories to test, and there are no treatments and no manipulations of variables.

In the qualitative case study, the researcher is the instrument for data collection. The researcher interviews, observes, interprets, and senses what is occurring. The study is usually conducted in the natural setting of the subject under study. In other words, the researcher goes to the people or the site to observe the behavior in its natural surroundings.

I have chosen the single-case study methodology to examine the BPCC because this methodology lends itself to developing an understanding of the processes, behavior, context and dynamics of collaborative and cooperative transborder relationships. Furthermore, qualitative methods of inquiry can best examine decision making 
processes as a general process in a group context. In addition, the BPCC is a unique entity established by the Mayors of San Diego and Tijuana, and no other such entity exists in the San Diego-Tijuana transborder region. Thus, a single-case study design is most appropriate. Moreover, the case study method offers a means for investigating complex situations. It can provide information about the characteristics and structure of the BPCC as a transborder entity. Multiple factors involved in transborder relationships can be identified, and the case study can facilitate the development of future research in the area of transborder policy-making and change in the San DiegoTijuana region.

The data generated by the case study of the BPCC can be used for illustrating and presenting information about the BPCC as an entity and can define the type of collaborative leadership relationships that makes it possible for the BPCC to achieve its goals. It can also be used for future comparisons, theory building, and to conceptualize different collaborative approaches in the transborder region.

\section{Research Design}

The following section describes the unit of analysis that I investigated. The sample strategy that I used to 
select my unit of analysis is what Chein (1981) calls

purposive sampling. Purposive sampling is conducted before collecting the data and is based on the assumption of the researcher wanting to discover, explore, understand and gain insight into a particular situation or group. In this single-case study, the BPCC is the unit of analysis, that is the entity selected for inquiry, due to its unique membership, role and function in coordinating transborder projects.

The data were collected during a nine month period and consists of detailed descriptions of the structure, form, decision-making processes, and interactions of the BPCC via interviews of the subjects and observations of the general monthly meetings. I also used multiple methods of data collection. As such, I triangulated interviews with observations and review of archival records to study the unit of analysis (Mathison, 1988).

\section{The Interviews}

I conducted 14 structured interviews over a period of six months and attended 3 BPCC meetings where I was a nonparticipant observer. In the structured interview process I posed initial guiding questions that generated additional impromptu questions (see Appendix C). The questions used reflect the type of information I was seeking, and included 
experience/behavior questions; opinion and feeling questions; and knowledge and background questions (Patton, 1980). The length of the interviews ranged from one to two hours and entailed questions that addressed the following:

(A) The form and structure of the entity;

(B) The role and function of BPCC regarding transborder collaboration:

(C) How the BPCC collaborates and makes decisions on joint regional projects;

(D) What processes does the BPCC carry out to fulfill its leadership role;

(E) The need for strategic planning for the region; and

(E) The need to maintain or restructure the BPCC and/or create a different entity.

I conducted the interviews at the subject places of work on both sides of the border. Six interviews were conducted in Spanish and the remainder were conducted in English. Verbal permission to tape-record the interviews was acquired and all participants agreed to the taped interview. Once the interviewees read and signed the consent form, they were given the opportunity to ask any clarifying questions regarding the research study. All interviewees were asked the initial guiding questions and 
impromptu questions were added depending on the responses of the interviewees.

\section{General BPCC Meetings}

I observed 3 different general monthly meetings, as a nonparticipant observer. The meetings alternately were conducted in San Diego and Tijuana interchangeably. At these meetings the City Managers from San Diego and Tijuana co-chaired and convened the meetings. The format of the meetings included updates from the City Managers on specific issues and reports from the co-chairs of each of the work groups were presented. The tone of the meetings are formal, and they lasted between three and four hours. In the second meeting that I attended I did a ten minute presentation of the research study and what it entailed. Note-taking supplemented the interviews and the general meeting observations.

\section{Archival Record Review}

I reviewed relevant documents and similar transborder agreements. Archival records, public documents, related studies, web-sites, and the agenda of general meetings were reviewed as well as reports. The archival records reviewed included files on the BPCC. These files are kept by the Manager of the Office of Trade and Technology for the City of San Diego. The office serves as liaison for the City of San Diego with Tijuana and 
coordinates the Letter of Agreement between the two cities. These documents included historical memos and reports dating back to the beginning of the BPCC in 1993. The files documented the developments of the BPCC in the last five years, including work plans from the work groups and correspondence between city officials from San Diego and Tijuana.

\section{Entry to Population}

I presented letters of introduction to the research study to the City Manager of San Diego and the Director of Coordination of the City of Tijuana, who jointly convene and chair the BPCC, (see Appendix D). The letters include the purpose of the study, the objectives, and the method for gathering data. Following agreement in writing from the City Managers to conduct the study (see Appendix E), I sent letters to the BPCC membership who are the co-chairs of the work groups, informing them of the approval of the study, (see Appendix F). In addition, the letter included the purpose of the study, the methodology to be used and the request for their participation in the study. I followed up with telephone calls to clarify any questions they may have had regarding the study and to schedule interview appointments.

The interviews that I conducted in Tijuana were the most 
challenging because of the distance, the time required to cross the border, and the accessability of the interviewees, not to mention having to cross-translate the interviews into English and different cultural context. On different occasions I had to reschedule some of the interviews from Tijuana due to unanticipated events across the border such as holidays, last moment schedule changes, and different business hours. All the interviewees appeared candid in their responses and eager to participate and collaborate. The interviewees' demeanor varied from open frank discussion to guarded responses.

\section{Selection of Subiects}

The subjects selected for the interviews were the twelve co-chairs of the work groups and the two city Managers who are the BPCC coordinators who convene and coordinate the work of the Committee. The BPCC is composed of six work groups, each with two co-chairs representing San Diego and Tijuana respectively. These work groups are: Libraries, Arts, Recreation and Culture; Public Works and Services; Public Safety; Planning and Land Use; Environment and Recycling; and Economic Development. The composition of the work groups included staff assigned to specific projects and invited guests from the private sector or academic sector. The guests were invited at the discretion 
of the co-chairs, depending on the project the work groups were carrying out. In total, 14 interviewees were the subject pool of the research study. Each subject was interviewed once. The Spanish language interviews tended to last almost an hour longer than the English language interviews.

To ensure the right to privacy, all of the interviewees signed the informed consent. The informed consent was in both languages (see Appendix G), and informed the subjects that I would refrain from using their names in order to preserve their anonymity. The interviewees were also informed that there might be some risk from, inferences of their identity through reading the results, and thus there might be some unwelcome publicity. These risks were minimized by providing the subjects with the informed consent to participate and by informing them of their right to withdraw from the study at any one point. The interviewees were given the opportunity if they so requested, to review the transcriptions and my assumptions, so as to further safeguard their anonymity. None of the participants requested their transcriptions. However, they were interested in receiving the completed study. I informed the interviewees that the name of the BPCC would be used in the publication of the findings. They were also 
informed that the tape recordings would be destroyed at the conclusion of the study.

The overall issue of ethics in conducting research is a consideration that I followed during the collection of data and the dissemination of the findings. The data collection methods that I used, interviewing city officials from both sides of the border and observation of the general meetings, posed inherent ethical dilemmas that I was aware of and attentive to. Specifically, I had to be careful about quoting verbatim the participant's comments in the findings. Paraphrasing the individual statements and presenting them in the aggregate ensured that the participants identity would not be inferred by their comments. Federal and professional guidelines of ethical conduct were followed, as mentioned above.

\section{Data Analysis}

The data analysis was guided by the existing relevant literature on globalization, binational relations and transborder economic relationships, as well as aspects of leadership and organizational theory. The literature on U.S.-Mexico relations, was explored and provided the historical context for the discussion of the development of local transborder institutional structures and collaborative efforts. Lastly. I reviewed the literature 
on organizational structures, so as to provide and additional perspective and understanding about the form and structure of the BPCC, in addition to its modus operandi.

In qualitative case studies the design is an emergent process that requires the refinement of one's hunches, working hypotheses, and educated guesses (Merriam, 1988). In the process of analysis, I organized, sorted, reduced, and consolidated the data into categories. For example, in devising the categories I clustered phrases, sentences, and concepts that converged into a similar pattern or theme. As such, responses referring to the organizational

structure of the BPCC were identified as characteristics or properties of the category : "organizational structure of the BPCC." Characteristics and properties of two other categories, "strategic planning" and "transborder collaborative relationships" were also identified from the data. I used open coding techniques to conceptualize and analyze the data, including line-by-line analysis of the transcribed interview text and identified similar units of analysis such as phrases and sentences and grouping them around the initial guiding questions (Lindbloom and Guba, 1985).

For purposes of this study the data is presented as aggregate or cluster data and interpreted in narrative 
form, so as to present a descriptive account of the findings. This analysis yields categories that represent emerging patterns, themes or concepts in the data. I analyzed the findings based on the responses to the interview questions and related issues pertaining to:

0 The intended form and structure of the organization or entity

0 The actual form and structure of the BPCC

- Decision making processes of the BPCC

- Strategic planning for the region

0 Differences between strategy and strategic plan

- Maintaining or restructuring the BPCC and/or developing a new entity

- Transborder collaborative leadership relationships The results of the analysis appear to yield valuable information on the potential for the BPCC or another entity to be the interlocutor for decision-makers on both sides of the border. Furthermore, the findings may help to clarify if there is a need for this entity to maintain the same structure, restructure, or create a different entity that can be the forum for collaborative strategic planning for sustainable development of the region. 


\section{critical summary}

My decision to focus on a single-case study methodology stems from my interest in presenting a holistic description of the BPCC and to develop an understanding of its organizational structure, processes, behavior and its collaborative partnership. The findings that unfold in the study of the BPCC may bring to fruition different insights into the development of alternative structures and initiatives on sustainable economic development for the transborder region.

The potential benefits of this methodology include provoking an increased understanding of the issues surrounding the BPCC as a structure and its purpose in the region. 
CHAPTER FOUR

EINDINGS AND ANALYSIS

"Truth is a matter of consensus among informed and sophisticated constructors, not of correspondence with an objective reality" (Guba and Lincoln, p.44, 1989).

Introduction

In this chapter, I use the results of the 14 interviews, the review of archival public records, and the description of observations of the Binational Planning and Coordination Committee (BPCC) meetings to describe what currently appears to be both an informal and formal structure of operation. I describe the role and function of the BPCC, its decision-making processes, and its collaborative leadership relationships as reported by the interviewees as key dimensions in the San Diego-Tijuana transborder partnership.

The need to develop sustainable economic development strategies for the region, and a strategic plan, were consistent findings in the data. On the other hand, discussing the restructuring of the BPCC or establishing a different institutional entity was a more challenging issue for the interviewees. The findings on this issue suggest a divergence of opinion among the membership.

I identified three needs as themes from the data and synthesized each in the analysis of the BPCC, revealing a) 
the need for a new agenda : how the structure of the BPCC facilitates the goals and objectives of the Letter of Agreement and how restructuring of the BPCC and/or developing a new institutional entity may facilitate a new economic agenda for the transborder region, b) the need for economic strategies: the need to develop unified strategies for sustainable economic development in the San Diego-Tijuana region; and c) the need for collaboration: the relational importance of transborder collaboration and cooperation among the BPCC leadership.

Concerning the need for a new agenda, a consistent finding was that the structure of the BPCC is characterized by informal and formal processes that allow for the development of transborder cooperation and the coordination of projects. These processes are manifested in the form and functions of the BPCC, in its decision-making process, and in its modus operandi. The issue of restructuring and or creating a new entity was a perplexing issue for the 14 interviewees, suggesting divergent points of view and the need to explore this issue as a near future agenda.

Regarding the need for economic strategies, the findings revealed overwhelmingly the need to develop sustainable economic development strategies for the region. Furthermore, the findings also reinforced the need to 
develop a strategic plan that would bring together in a concerted effort multiple strategies to address the region's needs.

In regards to the need for collaboration, the findings strongly suggest that the BPCC success to date is forged in the collaborative and cooperative leadership relationships of the players. These relationships are the catalyst for achieving the purpose and goals of the BPCC.

\section{Regional Context}

The United States-Mexico border is one of the few regions in the world where a major industrial capitalist nation and a developing or emergent nation share a national boundary. Nevertheless, the two nations share much more than a boundary. According to the 1990 US and Mexican Census the combined population of the San Diego/Tijuana region is approximately $3,000,000$ creating the most populous region along the U.S.-Mexico border. The border region is also a filter for the dynamic interplay of economic flows such as trade, commerce, manufacturing plants, tourism, services and research and development, which create a mutually dependent economic zone. It is also here where one industrialized, affluent and technologically developed society meets another culturally and linguistically distinct society. 
Within this functional interplay of asymmetries, the San Diego/Tijuana border region is posed with a most challenging dilemma, that is, the integration of the transborder region. Moreover, this cross-border relationship is beset with economic problems, migratory and environmental conflicts, infrastructure deficiencies and border space issues. Given the aforementioned dimensions of the issues throughout the past 20 years, concerted efforts have been made to address these issues. Multiple task forces, committees, work groups, forums and independent actors have attempted to bring to fruition what the BPCC seems to be accomplishing, that is, a herculean effort to confront a multiplicity of common problems, issues and solutions that impact the transborder region of the cities of San Diego and Tijuana. This partnership is also seen as necessary to present a joint and common voice to Washington, DC and Mexico City in matters related to the North American Free Trade Agreement (NAFTA) and in local regional planning. Most often, these initiatives are negotiated at the federal level with little to no input from the local political structure.

\section{The Need for A New Agenda}

\section{Intended Structure of the BPCC}

I describe in this section the structure of the BPCC as 
articulated in the Letter of Agreement, followed by the interviewee's own perceptions of how the BPCC actually functions, how it carries out its purpose and what forms of decision making are utilized to achieve the goals. In addition I present the findings on the issue of maintaining the same structure of the BPCC, restructuring the BPCC or developing a new entity.

In 1993 the City Governments of San Diego and Tijuana articulated in a Letter of Agreement the purpose and functions of the BPCC. The purpose of the committee is to facilitate the exchange of information, and enhance cooperation between San Diego and Tijuana (see Appendix B). To carry out the Letter of Agreement a committee chaired by the Mayors of San Diego and Tijuana and co-chaired by the City Managers of both cities was established. The City Managers lead the monthly meetings of the BPCC and facilitate the work of the Committee. Quarterly meetings are led by the Mayors. Six work groups were identified to carry out the tasks of the BPCC. Each work group has a co-chair from each side of the border and these co-chairs are heads of city departments and they are appointed by their respective City Managers. The work groups are: Economic Development, Planning and Land Use, Public Safety, Libraries, Arts, Culture and Recreation, Public Services 
and Environment and Recycling. Work plans for each of the groups are developed jointly and updates on projects are presented in the monthly meetings of the BPCC. Projects according to the Letter of Agreement are to be defined in detail, including the scope and priority of effort. Time lines are identified as well as members who are then expected to be responsible for project completion or action. Additional "spin-off" committees have been established in the last six months, such as Emergency Management out of the Public Safety work group, and Border Crossings, Transportation, and Water and Sewer out of the Public Service work group.

On July 31, 1997 the Mayors ratified the Letter of Agreement and the work plans for 1996-1997, (see Appendix H). These work plans establish the basis for binational collaboration in the areas of emergency management, water and sewer, public works and service, public safety, environment and recycling, libraries, arts, culture and recreation, planning and land use, economic development, border transportation and technology, Manager's Report, Report No. P.97-110, June 25, 1997, (see Appendix I) . The BPCC as an entity provides the structure for the City of San Diego and the City of Tijuana to coordinate regional projects and plans for the two bordering cities. 
The Manager's report of June 25, 1997, acknowledges the multiple challenges that face the BPCC in their binational planning efforts. The document states that the form of the two governments, their financial resources, cultural attitudes, decision-making and planning processes are different on both sides of the border, and finding synergy among the two border cities is a challenge. Furthermore, the report recognizes that there are multiple entities from both cities involved in related issues surrounding the San Diego-Tijuana border corridor. Many plans and projects for the area are in existence, yet no one agency or entity has the coordinating authority. The BPCC is seen as the organizational structure in this document to implement a binational plan or strategy for the region. It is important to note, that this is the first time a joint agreement was presented to the San Diego City Administration.

Actual Form and Function of the BPCC Structure

The findings reveal that the BPCC has an informal and formal structure. All 14 interviewees agreed that the informal organizational structure facilitates the accomplishing of actions, projects and coordinating functions necessary to get things done. The formal aspect of the structure is seen as legitimizing and 
institutionalizing transborder cooperation and efforts, thereby solidifying its purpose by sanctioning its role and function in regional binational affairs. The BPCC intended structure is one that is not legally sanctioned by Washington or Mexico, since it is unconstitutional for cities and states to enter into binational agreements. Yet this region enter into a cooperative agreement that is not binding, thus focusing on coordination of regional programs or projects on areas that do not impact sovereignty, national security or national interest. It is within this premise that the BPCC exists.

The complementarily of informal and formal processes of the BPCC can be understood from organizational frameworks to explain the nature of the structure of the BPCC. Every organizational structure has organization levels, goals, roles and linkages, (Bolman and Deal, 1984). As organizations become more complex, specialized and segmented, interdependence becomes essential for coordinating functions. The coordination of functions and tasks can be accomplished either vertically or laterally. Vertically, organizations command through authority and control and usually operate within a stable environment and a set of rules and standards. Lateral coordination occurs in organizations when staff or personnel coordinate with 
one another through meetings, task forces, and coalitions. There are usually few rules or procedures governing the activities of these participants. Lateral techniques include formal and informal meetings for developing plans, solving problems, and making decisions. The creation of committees and work groups bring different stakeholders from different areas and specialties together to work on a particular project. They coordinate roles and functions through persuasion and informal negotiation.

From an organizational perspective my findings reveal that lateral forms of coordination, which are typically less formal, are a process that is manifested in the BPCC and favored by the interviewees. Lateral forms of coordination are typically found in rational organizational structures that use this strategy to negotiate, persuade and problem-solve the issues at hand (Bolman \& Deal; 1984). This is favored because an informal, loose structure with its flexible boundaries and absence of standard operating procedures and rules facilitates working together and interacting across an international border. This, gives the appearance of cooperating in a seamless and borderless region. This loose structure also allows for the sharing of strengths and resources, and the interchange of communication and skill development through joint planning. 
This interchange of resources is carried out in a turbulent environment amidst a historical context beset by political, economic, social, cultural and linguistic barriers. All of the interviewees in one form or another verbalized the importance of building and developing working and trusting relationships to confront not only the tasks at hand but the barriers and challenges that exist.

The formal aspect of the BPCC is manifested in the governance structure of the entity. The BPCC was established and is led jointly by the two mayors and operationalized by the City Managers. This type of authority is found in traditional, rational organizations such as governmental structures described by (Bolman and Deal, 1984). This institutional level of authority is seen by the interviewees as the leadership that sanctions and legitimizes the coordinating functions of the BPCC in the transborder region. Projects that need the blessing of the Mayors, are those that the federal governments have authority over, such as border crossings, the environment and immigration issues. Decision-Making Processes of the BPCC

The process the BPCC is embarking on to effect change in the border region reflect issues, concerns, and problems that are jointly identified by the leadership. How the 
BPCC prioritizes these issues and makes decisions about which projects or actions should be taken is mostly carried out informally.

Decision making in the BPCC at best is an unclear process that happens at the three levels of the entity. There are decisions that sometimes are made at the Mayor's level, at the City Managers' level and, for practical purposes, most frequently at the level of the work groups. The interviewees reported a highly-valued level of autonomy by the work groups when it comes to deciding on projects and searching for solutions. There is no clear outlined decision making process for the BPCC outside of the content of the Letter of Agreement, which does not specify or identify a process. However, the work group members did ascertain that projects are formally presented to their respective City Managers for direction, input and sanctioning. Issues that are linked to the federal governments are coordinated through the Mayor's office for direction and approval.

It could be surmised that although there are no written rules and standard operating procedures for the BPCC, as heads of their City departments the interviewees are adhering to their own city administration's modus operandi. They also follow a set of international 
protocols as well as rules and standard operating

procedures of their respective governmental structures, which are guided by authority based rules and procedures often found in governmental structures. Political, public agencies operate amid constituencies, coalitions and interest groups that have a multiplicity of goals which may juxtaposed each other and at times be in conflict. Rules, operating procedures, and policies govern the work and the relationship with the environment (Bolman and Deal, 1984).

At the work group level, decision making was described overall by the interviewees as an informal and formal process, much like the structure itself. It is a loose process that is collaborative, shared decision-making, is a complimentary problem-solving, and a negotiating process that is confusing and unclear. The interviewees affirmed that the co-chairs on each side of the border agree on projects that are of mutual interest and they, with group members, search for gaps and solutions to address the issues.

The BPCC has three types of meetings: Quarterly meetings where the mayors lead the meetings, general meetings that are intended to occur on a monthly basis and lead by the City Managers, and work group meetings that are scheduled at the discretion of the co-chairs. At the 
quarterly meetings and at the monthly meetings all of the members, (i.e., the co-chairs) present their joint work projects, updates on actions taken, and time lines for project completion. The agenda is set ahead of time and these meetings are primarily used as a forum to disseminate and exchange information. During my observations at the general monthly meetings, I did not observe a formal process for decision making. The meetings were conducted in both languages, extending the length of the meetings. On one occasion, there was simultaneous translation provided. The interviewees reported that these meetings do not conform to a monthly schedule. In 1997 there were 5 general meetings conducted. During that year the City Manager for San Diego resigned and a new City Manager was appointed in September.

Meetings of the work groups range from as often as they were needed to once per week or biweekly. The frequency of these meetings depends on the project and the work group. Telephone contact such as fax, and E-mail were used as frequent measures of communication.

The findings suggest that the overall decision-making process of the BPCC does not conform to a structured formal decision-making process. Perhaps it can be noted that since the BPCC is not a policy-making entity and has no 
formal advisory capacity to the two city governments, there is no perceived necessity to make this process more formal. Nevertheless, the work groups overall seemed to value the existing decision-making process by virtue of its simplicity and the accomplishments made to date, mostly based on the "good will" of the people involved. This is not to imply that the process simplicity undermines the complexity of the issues or mutual problems that are brought to the table, especially in the context of international boundaries, sovereignty concerns, and the barriers referred to earlier.

The type of decision making practiced by the work group members of the BPCC seems to conform to and align those decision processes that are interactive, and found in political structures, human resource organizations and post modern intersect organizations.

Maintaining, Restructuring or Developing a New Entity

There seems to be a difference of opinion between the interviewees as to the need to restructure the BPCC. There are three divergent points of view that have implications for the border region. On the one hand, it appears from the findings that some entity, whether it is the BPCC in its present state or in a restructured form, somehow would have to address the present perceived need to develop 
unified strategies and a strategic plan for the region. Furthermore, a restructuring would formalize and institutionalize the entity and legitimize transborder cooperations, creating an advisory capacity for the two city administrations. This change in structure could facilitate, enhance and expedite the development of a new phase in regional sustainable economic development.

Four of the respondents reported they saw the need to restructure. Some of the reasons are related to the perceived need to have some kind of an umbrella organization that would bring together all the initiatives being carried out in the region. One interviewee stated that "a separate entity could serve as an overarching organization that sponsors the BPCC." Another interviewee stated that: "the BPCC could restructure as an entity that could expand to include partners in other sectors such as the private and academic sector, thereby increasing the potential of the BPCC." These sectors at present are not members of the BPCC, though, they participate at the invitation of the work groups when requested. Another interviewee mentioned that: "by consolidating some of the existing committees and task forces, the BPCC could enhance its planning initiatives." The fourth interviewee reported that: "by restructuring, the BPCC would be able to develop 
economic strategies and become an advisory group to the two city governments on economic development."

On the other hand, some of the interviewees do not see the need to restructure. Six of the interviewees do not see the need to restructure due to existing multiple barriers that to a great extent are inherent in any binational and/or regional relationship. The six members would like to maintain the existing structure and maintain the same mission and goals. They gave the following reasons as to why it would not be in the interest of the BPCC to restructure:

The BPCC fulfills its purpose as is; bureaucratization of the cooperative process could result in an inability to get projects done; it is not within their purview to decide on this issue; the present institutional barriers within the two city administrations; the local conservative political climate would impede this development; there are sovereignty issues; multiple divergent interests, and there would be a lack of financial resources to establish such an entity. 
Lastly, four other interviewees expressed interest in the development of a new entity with a broad range of powers that would provide policy direction in the transborder region. This would not necessarily eliminate the BPCC. It would however, according to this four provide opportunities that are non-existent in the present structure. It appears that the perception towards restructuring the BPCC or developing a new entity requires an in-depth assessment and analysis of its effects on future directions for the region.

Changes in the nature of any organization requires transformation when the traditional organization can no longer respond to the demands of the environment and the market place. Restructuring an organization requires a new mission and a vision that is consistent with its new purpose. This new organization necessitates new forms of communication, collaboration, influence and decision making. Its boundaries are flexible, with various constituencies incorporated such as blending the public and private sector among others. Partnerships must be guided by a collaborative, open and consensual dialogue to create a unified purpose and problem solve the myriad of challenges facing the 
organization. Hecksher and Donnellon, 1994 refer to this type of organization as the post-bureaucratic organization and conceptualize this type of organization as being interactive and relying in informed consensus rather than on hierarchy and authority alone.

\section{The Need for Economic Strategies}

Strategic Planning for the Transborder Region

There is a substantial body of literature in the field of strategic planning that describes strategic planning as a process with specific steps and tasks. The process of strategic planning is seen as an incremental activity taking place over time, involving multiple players at different levels of an organization (Mintzberg, 1978, and Lindbloom, 1959) and having goal formulation, environmental analysis, strategy formulation, strategy evaluation, strategy implementation and strategy control (Schendel \& Hoffer, 1979). Furthermore, (Pettigrew 1985) suggests that strategic decision making has to be carried out within a political and cultural context. Another well known approach is the long-term strategic planning favored by the Japanese and exemplified in an expression by the President of Nissan, Mr. Ishihara: "In what I do now, I 
am thinking twenty or thirty years ahead" (Zaikai, 1983: 10-11, 6) .

Strategic planning for the San Diego-Tijuana region requires a long term vision to develop a comprehensive sustainable economic plan that addresses the region's opportunities and challenges in order to shape the economic future of the zone. The development of such a plan requires the commitment of multiple resources to achieve a diversified economic base and improve the quality of life.

While San Diego and Tijuana have been collaborating on transborder economic issues over a span of thirty years, a joint strategy has not been forthcoming. Thus, there is a growing consensus and belief by an extensive array of interest groups that represent the public and private sector, academia, and non-governmental entities from the San Diego/Tijuana region about the need to develop a joint vision on economic sustainable development for the region. It is also the perception that economic strategies and a comprehensive plan is needed to articulate a joint vision for the region.

Moreover, there is a multiplicity of established forms of cooperation, manifested in actions and 
initiatives, as well as within work groups, committees, associations, task forces and governmental entities involved in transborder cooperation. Consequently, there is also the perception by some that an umbrella organization or entity would bring these initiatives and actors together to form a unified coherent strategy in cross-border collaboration (Lopez \& Clement, 1996). With these premises in mind, I explore in the following pages these issues via the interviews, the observations of the general monthly meetings and review of archival records of the $\mathrm{BPCC}$.

The need to have a master plan or a strategic plan was affirmed by 12 of the 14 interviewees. The interviewees agreed that there is a need to bring together existing initiatives into a coherent, mutually developed strategy. Overall, the interviewees perceived that there is "fragmentation, duplication of effort and scarcity of resources." These factors point to the need to develop a consorted strategy in transborder planning. The subjects also felt that: "continuity of projects would be ensured and redundancy would be addressed with a focused strategy." It was also felt by the group that a strategic plan would: provide a continuous transborder 
vision with goals and objectives that would be measured not only by the impact on sustainable economic development of the region but by accomplishments that mutually benefit the border region.

The subjects interviewed stated the need to develop a plan in a collaborative fashion. There was wide recognition of the complexity of the task and the recognition that there were inherent challenges or barriers to the development of a plan. The cohort of challenges described by the interviewees include:

the questionable community and political support for such a plan; the socio-political climate of the United States towards its southern neighbor; existing binational statutes that preempt border states and cities from engaging in accords; the economic disparity between the two cities; and the linguistic and cultural nuances of each. Nevertheless, some of the participants opined that in order to develop a master plan, "the need has to be established" and it appears that the BPCC as a group has not framed this need concretely. One participant in the group also stated that: 
once the need is established, fiscal resources have to be allocated to this endeavor as well as bringing together planning experts in the field of transborder economic development to facilitate the development process.

Another interviewee mentioned that:

a strategic plan would institutionalize the collaborative process, provide continuity over time,shape regional economic development, prevent duplication of efforts and clarify the issues at hand, thereby, facilitating solutions at a local level, and maximizing the opportunities that an economic or metropolitan region would bring.

The above comments do not imply that the BPCC from its inception has not developed work plans or action plans that address cross-border concerns. Following the Letter of Agreement, the BPCC has identified mutual areas of cooperation in specific areas and has carried out viable projects over the last five years. Appendix I list the work plans ratified in 1996-1997. Difference Between a Strategy and a strategic Plan An interesting finding from the interviews is how the group confused the need to develop a strategy for 
the region and the need to develop a strategic plan for the region. My assumption here is that cross-border or transborder cooperation necessitates multiple strategies to address different market sectors on both sides of the border. Sectors such as service, finance, business, industry, economics, transportation, infrastructure, communication, technology, and the environment need specific planning efforts and initiatives. A regional strategy also necessitates a needs assessment of the region's efficiencies and deficiencies in the above areas, which would facilitate managing the issues and planning efforts. This assessment would also identified the established groups that exist, thus creating a resource directory of stakeholders.

The degree and extent of cooperation that already exists through the BPCC and other independent efforts can also be seen as a transborder strategy. The intensification of cross-border cooperation over time can also inform the need to develop different kinds of structures and entities to facilitate actions and institutional arrangements similar to those of other region states.

A strategic plan or master plan, on the other 
hand, would be the blueprint or framework that bring these and other strategies into a coherent plan. This plan would serve as a guide to move the region forward and position the region in the global market economy.

\section{The need for collaboration}

\section{Transborder collaborative Leadership}

To meet the challenges posed by a world that is constantly changing, the ideal organization will have to become increasingly interactive and rely on informed consensus. Collaborative leadership relationships will be based on forms of influence that enhance mutuality and collaboration in decision making. Influence and persuasion facilitates the response to community, market demands and changes. It is within this context that the next section examines the collaborative relationships of the two cities.

Transborder collaboration and cooperation was perceived by all of the 14 interviewees as among the most essential aspects of laboring towards a common purpose. The group stated that: "a high level of collaboration and cooperation exists among the membership of the BPCC, facilitating solutions to address common border issues." The levels of 
collaboration and cooperation were also described both as informal and formal, which is consistent with the stated findings already alluded to in reference to the form, structure and decision making process of the BPCC. The development of relationships either informal or formal facilitates coordination of actions, projects and efforts on specific issues identified by the membership. The extent, scope and breadth of these relationships influence the process and the end result. The interviewees said that the leadership of the BPCC is characterized by the "good will" of the participants to work in collaboration towards mutual goals. This is significant in that the BPCC is a nonbinding entity; hence, what makes this entity accomplish its objectives is the collaborative relationships. Dialogue, developing relationships, bargaining, negotiation, and persuasion are some of the behaviors that characterized the interviewee's modus operandi and dealings with each other. This type of collaboration can be found in political organizational structures and intersect organizations. In essence, the leadership of the BPCC functions in a collaborative, relational context, which is characteristic of forms of leadership described by 
(Burns, 1978 and Rost, 1992).

Furthermore, the group affirmed that:

the interdependence that each city has with the other at multiple levels in such areas as economic development, tourism, services, infrastructure, the environment, and social development, accentuates the need to develop, maintain and further develop cross-border relationships.

It was the perception of the interviewees that by collaborating and cooperating with each other in the exchange of ideas, concepts, information, transfer of technology and skill-based education, they are influencing and impacting the development of the border region and the quality of life on both sides.

Although there is a clear pattern of collaboration and cooperation between the two cities there are recurring barriers that appear to make transborder collaboration challenging at best in the region. Factors that are repeatedly mentioned by the interviewees relate to "the disparity in economic development, technological know-how, the diverse political structures of the two countries and the historical context in which these relationships evolve 
over time as well as the cultural idiosyncracies of each."

All these variables influence present-day regional cooperation and collaboration. It should be noted that the EU has recently undergone a similar experience, most notably with the latest inclusion of Spain, Portugal and Greece into the EU.

overall, the interviewees felt that the purpose and goals of the BPCC were being fulfilled as dictated by the Letter of Agreement. This assertion was juxtaposed with the opinion by some of the interviewees that its potential has not been fulfilled and it remains to be seen, in light of the present regional and global market demands, whether it proves sufficient to the task.

\section{critical summary}

The findings of this case study demonstrate that the informal and formal structure of the BPCC facilitates the coordination of activities and projects between the cities of San Diego and Tijuana. It is important to note as well the apprehension revealed by some of the interviewees about institutionalizing the structure and thus the process. These interviewees opined that redefining the BPCC structure or creating a 
new entity would hamper or add complexity to the process, thereby creating additional bureaucratic and regional challenges. On the other hand, one can surmise that if the form and structure of the BPCC remains intact and the restructuring or establishment of another entity is not decided upon, the maximization of opportunities in initiating strategies for sustainable economic development for the region would be less than a reality. The findings also suggest the need to explore further alternative structures to respond to the transborder economic needs of the region with a long-term vision of the future. In addition, the study yields information on the need to develop sustainable economic-development strategies for the transborder region. Lastly, the study provides insights into collaborative leadership relationships vital to understanding transborder pursuits.

In conclusion, the study develops some preliminary findings that reveal future directions and opportunities for the economic development of the San Diego-Tijuana region.

The most significant finding was revealed when 12 of the 14 interviewees reaffirmed the community perception that consorted economic strategies for the 
transborder region are needed and necessary, in addition to developing a blueprint that would articulate the needs and the strategies to accomplish the vision for the region. It is noteworthy to underscore as well, that the interviewees acknowledge the inherent challenges and barriers in moving this agenda forward. The cohort of challenges include the community and political support for such a plan and the socio-political climate of the region, among others. This complexity, is inherent in binational and international relations as mentioned before.

Lastly, all 14 interviewees stressed compellingly the importance of collaboration and cooperation within a relational context. It was often mentioned that the good will of the BPCC leadership was the main factor for achieving the mutual purpose and goals of the BPCC, since the BPCC is not a binding entity. This good will is forged in the relationships that the interviewees and the cohort of staff and interested others have developed through informal and formal mechanisms of the BPCC. Interdependence and a common purpose and goals was essentially seen as the glue that binds the relationships, and thus the efforts, to solve the region's problems. 
The above findings yield an important glimpse into the BPCC and provides a window of opportunity for the next stage of development for transborder sustainable economic development for this region. 
CHAPTER EIVE

SUMMARY, IMPLICATIONS AND RECOMMENDATIONS

"The cities with the greatest economic potential in the 1990 s will be those which possess a diverse economic base, qualified human capital, strong local linkages with knowledge-based institutions, a high quality of Iife, modern telecommunications and transportation links and the institutional capacity to develop and implement future-oriented development strategies" (Commission of the European Communities, 1992 p.22).

\section{Introduction}

This chapter presents a summary of the issues being explored and the findings of the case study of the BPCC. Furthermore, it articulates the implications of the findings and the limitations of the study. Finally, it chapter concludes with recommendations to the multiple actors involved in sustainable development for the transborder region of San Diego and Tijuana.

\section{Summary of the Issue}

The purpose of this single case-study is to examine and analyze the Binational Planning and Coordination Committee (BPCC) in light of the growing concern over the lack of transborder strategies on sustainable economic development in the San DiegoTijuana region (Clement and Zepeda, 1993). The study seeks to understand the role and functions of this entity, its form and structure, and its collaborative 
and cooperative functions in the border region.

Furthermore, I present the perceived need in the region to establish a binational entity or structure that can have oversight and a broad range of powers, such as making recommendations on policy directions to the two local governments on sustainable economic development (Report of the Binational Task Force on Economic Development and Transportation Infrastructure, September 30, 1993).

Transborder collaborative partnerships and efforts were explored within a historical perspective of nation-state boundaries and the globalization of common markets in the twentieth century. In the dawn of the twenty-first century, the literature illustrates the development of region-states as the hallmark of sustainable economic development in regions such as the San Diego-Tijuana region.

Against this backdrop, I examined the transborder region of San Diego and Tijuana in light of U.S.-Mexico relations, the existing economic and socio-political interdependence of the region, the implementation of the North American Free Trade Agreement and the strategic geographical location of the two cities for market opportunities with the Pacific Rim and Latin 
America. Furthermore, I present a review of local San Diego-Tijuana institutional entities preceding the BPCC, as precursors of established attempts to formalize linkages and working relationships in the border region. I explored organizational structural frameworks to explicate the structure and the processes that the BPCC utilizes in carrying out its mission. I chose a qualitative case study methodology to describe and analyze the structure and the processes of the BPCC. This methodology is best suited for analyzing an individual, a setting, an event, a group, an institution or an entity. While there are other qualitative methodologies, such a ethnography, phenomenology and hermeneutic methods of inquiry, the case-study methodology presents a especially holistic description of the phenomenon under study. I investigate in depth the processes, role and functions, and the structure of the BPCC. This methodology illustrates the complexities of the BPCC as an entity, the need to develop concerted strategies, the need for a master plan that would move the economic agenda for the region, and the differences of opinion on the issue of restructuring the BPCC or creating a new entity that would bring the existing initiatives together in a 
common agenda for the region.

The philosophical underpinnings of a case study lie within the realm of naturalistic inquiry. Its purpose is the understanding of meaning in an experience through inquiry, observation and sensing what is occurring. I collected the data by interviewing the 14 participants who are the members of the BPCC. Twelve members are the co-chairs of the work groups and two members are the conveners and coordinators of the BPCC. These members are appointed City officials from both sides of the borders. I gathered the data through structured interviews, by reviewing archival records and in non-participant observations at 3 general monthly meetings.

I organize and consolidated the data into units of analysis (Lincoln and Guba, 1985) that were similar and represent emerging themes or patterns in the findings. The data were then coded and grouped in conceptual categories. I identify three overarching themes and describe the findings of the data based on the pattern of interviewee responses and the plausibility of the data. They are: a) the need for an agenda: how the structure of the BPCC facilitates the goals and objectives of the Letter of Agreement and how 
restructuring of the BPCC and/or developing a new institutional entity may facilitate a new agenda for the transborder region, b) need for economic strategies: the need to develop a unified strategy and a blue print for sustainable economic development in the San Diego-Tijuana region, and c) need for collaboration: the relational importance of transborder collaboration and cooperation among the BPCC leadership.

These three themes are inherently interdependent and provide an understanding and insight into transborder cooperation within the BPCC as an entity, and suggests the ground work that remains to be done for the San Diego-Tijuana region in sustainable economic development.

\section{Findings}

Need for an agenda: The structure of the BPCC facilitates the goals and objectives of the Letter of Agreement and how restructuring the BPCC and/or developing a new institutional entity may facilitate a new agenda for the transborder region.

The findings in this theme reveal that the BPCC has both an informal and formal organizational structure that facilitates and carries out the present 
mission and goals of the Letter of Agreement. That is, it accomplishes actions, projects and coordination of functions in the transborder region. Formal aspects of the BPCC are evidenced by the positional leadership of the Mayors and the city officials that make up the membership of the BPCC. The Mayor's Letter of Agreement institutionalizes and legitimizes the transborder collaboration and cooperation. The Agreement sanctions the BPCC as an entity that coordinates joint efforts on transborder issues. The informal processes of the BPCC are best described as lateral forms of coordination manifested in loose organizational structures with flexible, open boundaries and relationships of trust are key ingredients as described in the interactive organization of Heckscher and Donnellon, 1994. Bolman and Deal (1984) depict rational bureaucratic organizations that use lateral forms of coordination to persuade and negotiate the agenda and the end result of group processes. The BPCC uses the work group format and its lateral forms of collaboration and influence to cooperate in joint transborder projects.

Lateral forms of coordination in the BPCC include the work groups, conducting informal joint meetings, 
sharing of resources, transfer of skills and the building and development of working and trusting relationships. The interviewees favored the informal aspect of the BPCC and remarked that because of its informal processes, working together and collaborating in joint projects reduced the existing barriers and decreased the existing complexities of working in the transborder region.

Decision making in the BPCC was a process that was perceived as unclear, yet interviewees reaffirmed that this too was an informal process that most often happens at the work group level. The co-chairs prize themselves on the level of autonomy they have on choosing projects and searching for solutions. The process was described as collaborative, as shared decision-making, as complimentary problem-solving, and as a negotiating process that was at times unclear and confusing. There are no BPCC By-Laws or written policies that outlines a decision-making process. This type of decision-making process is commonly found in intersect organizations that utilize process design teams and project teams.

It is important to note that overall the interviewees valued the informal processes and existing 
structure of the BPCC. They affirmed that this

flexible, "virtual organization," by its very nature, allows for the accomplishment of the its mission and purpose in a transborder environment filled with complexities, asymmetries and challenges. The BPCC was identified by a few of the interviewees as a "virtual organization" because it exists within two distinct governments and political administrative structures that have a rational and traditional bureaucratic approach to conducting the business of its constituencies. Yet, the essence of the BPCC is to operate within a flexible process of collaboration and cooperation to achieve its common purpose.

The findings also revealed divergent points of view and opinions on the issue of restructuring the BPCC or developing a new entity that would have a broad range of power, and could address sustainable economic development for the region. Four of the 14 interviewees recognized that by expanding the membership to include a broad base representation, and consolidating some of the existing planning initiatives, work groups, and committees into a larger umbrella organization, the BPCC would be better able to develop economic strategies for the region and have 
advisory capacity to the two city governments on economic development. Four other interviewees expressed interest in developing a new entity with similar functions and purpose as described by the four interviewees who stated that the BPCC can be restructured.

Six interviewees did not perceive the need to restructure or create a new entity. These interviewees opined that they would like to see the BPCC remain the same and continue to fulfil its mission. They gave multiple reasons, having to do with the bureaucratization of the cooperative process, present institutional barriers of the two government administrations, the local conservative political climate, sovereignty issues, multiple divergent interests, and lack of financial resources to establish such an entity.

In its present form, the structure of the BPCC fulfills the intent of the Letter of Agreement that institutionalizes the BPCC as an entity in 1993. However, the findings also suggest divergent opinions on the future of the BPCC as the conduit for change in the transborder region. The findings imply that at least the issue of maintaining the BPCC in its current 
form, or restructuring and/or creating a new entity, needs to be explored in depth. Thus, the joint leadership on both sides of the border needs to consider seriously this issue as a near future agenda.

From a developmental point of view, organizations and entities such as the BPCC need to consider their role and function in an ever-changing environment, and adjust to market demands that are no longer local, but transcend international borders. For the BPCC To remain static and stagnant is to not maximize with respect to the opportunities that knock at the door. The multiple challenges, presented as barriers impeding the development of a new structure or entity, are realities that have to be confronted, negotiated and solved. The vision and the commitment to change for the good of all, for the improvement of quality of life for all, and for sustainable economic development have to be recognized as necessary antecedents in bringing to fruition different ways to approach future regional directions.

The need for economic strategies: The data present a need to develop unified strategies for sustainable economic development in the San Diego-Tijuana region. The data related to this theme support the need to 
develop concerted sustainable economic development strategies as well as a strategic plan or blueprint to articulate these economic strategies. This finding reinforces the perception of an extensive array of interest groups that are represented in the public and private sectors, non-governmental entities and academic sectors. This finding was also substantiated in the review of the literature and in the review of archival records of the BPCC.

The above findings underscore the consensus of the interviewees on this issue. It also informs the audience that continuing in the present path will limit the competitive edge in the global market economy for the San Diego-Tijuana region. The repercussions would be felt in the industrial and financial sectors of the economy, and most importantly in the quality of life of the citizens of the region. On the other hand, the development of sustainable economic strategies would provide a competitive edge in the global market, therefore positioning the San Diego-Tijuana region as an economic zone and ensuring its successful participation in the global economy. This kind of economic progress productively employs the workforce and improves the quality of life in the region. 
The decision to develop concerted economic strategies for the region and a master plan go hand in hand with the need to rethink the functions and role of the BPCC and for that matter, the creation of a new entity. These two factors are intimately interwoven in the economic tapestry of the region. One cannot be consider independent of the other.

The need for collaboration: There is a relational importance between transborder collaboration and cooperation among the BPCC leadership.

Transborder collaboration and cooperation were seen by the 14 interviewees as the most essential aspect in fulfilling the purpose of the BPCC. The "good will" of the participants was repeatedly mentioned as the essence of collaboration. This factor is significant in that the BPCC is a non-binding entity. Therefore, the efforts of the participants stem from a desire and willingness to labor together for a common purpose and to solve mutually the challenges that the transborder region presents. Ultimately the continuous development of collaborative relationships is what usually makes or breaks a deal as the cliche goes. The nurturing rejinforcement from the development of trusting 
relationships undoubtably will make a difference as the community, interested others and the politicos embark on the future development of the transborder region. Without this relationship, collaboration and cooperation can have no meaning. Without dialogue, understanding, or acceptance of the differences of context and culture, the region will be less likely to prosper.

These three themes are intimately interdependent, as each impinges on the other to facilitate the future direction of the region. Without seriously considering the current environmental and market demands and the potential of an economic region such as San Diego and Tijuana, it will be difficult to institute sustainable economic development strategies for the transborder region. Without long term economic planning for the region it will be difficult to envision the kind of organizational structure that would facilitate the contiguous development of transborder relationships and cooperation that create an economic zone as described by Ohmae, 1990 in his book The Border Less World.

\section{Becommendations}

The San Diego-Tijuana transborder region is at a decisive juncture in its maturational development as an 
economic region in the global market. I suggest that in order for the region to seize the moment and the opportunities that lie ahead, a leap of consciousness is needed to guide the path towards a new economic agenda for the cross border region.

I recommend that the leadership of the BPCC, the two City administrations, policy-makers, the current stakeholders of the region on transborder issues, and interested others create as an initial step a forum to dialogue on the future direction of the region. Such dialogue can be guided by the findings revealed in this study and the existing literature that informs the need for sustainable economic development at regional, international and global levels.

Moreover, by socializing and politicizing the issues in public forums and bringing together the multiple initiatives that exist in the border region the leadership can define the needs and strategies as to the best course of action for this particular region based on the region's current level of economic integration.

Lastly, the plethora of efforts, organizations, groups and alliances that exist in the region create fragmentation and disparate responses that may not be 
in zinc with market demands. Exploring the consolidation of these initiatives and the restructuring of some of these efforts into an overarching entity that can formulate the vision for the transborder region can increase the competitive edge of the region in the global market and ultimately improve the quality of life of its citizens.

Examples can be drawn from the Seattle, Washington and Vancouver, Canada region. The Cascadia Corridor Commission (CCC), as it is known, was created by an act of the U.S. Congress in 1992. It established a binational, tri-state decision-making body to develop regional strategies for environmentally sound economic development in this region (Kiy, 1993). The Cascadia Corridor Commission has an advisory capacity to the local, state, and federal agencies with jurisdiction in the Cascade region. Different community sectors participate in developing common strategies on issues ranging form the environment, to growth management, water quality, education and transportation.

Another example of transboundary cooperation is the Regio Basiliensis in the Alsace-Baden-Basel region, a trinational coordinating and planning organization that overlaps France, Germany and Switzerland. 
Participants include the industrial sector, local government and universities. They have similar work groups as the BPCC and they develop recommendations on planning issues for the region. The region also has a regional Three Party Regional Committee that outlines the Basin's development problems and proposes possible solutions. The broadest of the bodies of this transfrontier cooperation is the German-French-Swiss Government Commission, and it develops recommendations for the contracting parties and is able to prepare draft agreements (Brinner, 1985). 


\section{REFERENCES}

Anderson, M. (1982). The political problems of frontier regions. West European Politics 5: 1-17.

Astin, H. \& Leland, C. (1991). A new perspective on leadership. In, H. Astin \& C. Leland (Eds.), Women of influence, women of vision (pp. 1-14). Acrossgenerational study of leaders and social change. San Francisco: Jossey-Bass.

Berquist, W. (1993). The postmodern organization. Mastering the art of irreversible change. San Francisco: Jossey-Bass.

Bevans, C.I. (1972). Treaties and other international agreements of the United States of America 1776-1949. Vol. 9. Washington, D.C.: U.S. Government Printing Office.

Boggs, S.W. (1940). International boundaries - A story of boundary functions and problems. New York: Columbia University Press.

Bolman, L.G \& Deal, T.E. (1984). Modern approaches to understanding and manging organizations. San Francisco: Jossey-Bass. 
Bosworth, B. Collins, S.M. \& Lustig, N.C. (1997).

Introduction. In B. Bosworth, S.M. Collins \& N.C. Lustig (Eds.) Coming together?: Mexice-United States relations (pp. 1-24). Wahington, D.C. The Brookings Institute.

Briner, H.J. (1986), Regional planning and transfrontier cooperation: The Regio Basiliensis. In O.J. Martinez (Ed.), Across boundaries: Transborder interaction in comparative perspective. El Paso TX: Texas Western Press.

Burns, J.M. (1978) . Leadership. New York: Harper \& Row. Bryson, J.M. \& Crosby, B.C. (1992). Leadership for the common good. Tackling public problems in a sharedpower world. San Francisco: Jossey-Bass.

Calavita, N. (1993). Measuring 'Quality of Life' in San Diego. In N. Clement \& M.E. Zepeda, Miramontes (Ed.s), San Diege and Tijuana in transitien: A regienal analysis (pp. 31-44). San Diego, California Institute for Regional studies of the Californias, San Diego State University.

Calder, J. R. (1977). An attribution theory of leadership. In B.M. Staw \& G.R. Salancik (Eds.), New directions in erganizational behavior (pp. 179-202). Chicago: st. Clair Press. 
Carrillo, J.V. \& Hernandez, A. (1985). Mujeres fronterizas en la industria maquiladora. Centro de Estudios Fronterizos del Norte de Mexico, A.C. Tijuana, B.C.N. Chavira, R. (1982). The new Tijuana: Now it's a magnet for Mexicans. San Diego Union, February 7.

Chein, I. (1981). Appendix: An introduction to sampling. In L. H. Kidder (Ed.), Selltiz, Wrightsman \& Cook's, Research methods in social relations. (4th ed.) New York: Holt Rinehart and Winston.

Clement, N., \& Zepeda, M.E. (1993). San Diego-Tijuana in transition: An overview. In N. Clement \& M.E. Zepeda (Eds.), San Diego-Tijuana in transition: A regional analysis (pp. 91-99). San Diego, CA: Institute for Regional studies of the Californias, San Diego state University.

Comprehensive Planning Organization (CPO), (1978).

Historical Trends: San Diego, CA: CPO.

Council of Europe, (1977). Harmonization of regional plans

in frontier regions. European Regional Planning

Studies Series. Strausbourg: Council of Europe. Dillman, D. (1969). Border town symbiosis along the Lower Rio Grande as exemplified by the twin cities: Brownsville (Texas) and Matamoros (Tamaulipas). Revista Geografica 71: 93-113. 
Dupuy, P.M. (1982). Legal aspects of transfrontier regional cooperation. West European Politics 5:60-63.

Fielder, F.E. (1967). A theory of leadership effectiveness. New York: McGraw-Hill.

Fronteras (1976). A view of the border from Mexico. San Diego, CA: City of San Diego.

Fry, E.H. (1992). The north american free trade agreement: U.S. and Canada perspectives. In J.A. McKinney \& M.R. Sharpless (Eds.), Implications of a north american free trade reqion: Multidisciplinary perspectives (pp.17-31) Baylor University.

Ganster, P. (1993). Transborder linkages in the San Diego-

Tijuana region. In N. C. Clement \& S.E. Zepeda Miramontes (Eds.), San Diego \& Tijuana in transition:

A reqional analysis (pp. 109-118). San Diego, CA:

Institute for Regional studies of the Californias, San Diego State University.

Gerber, J. (1993). Cycle and trends in San Diego and California. In N.C. Clement \& E.Z. Miramontes (Ed.), San Diege-Tijuana in transition: A regional analysis (pp.5-16). Institute for Regional studies of the Californias. San Diego State University, San Diego, CA 
Gibb, A.C. (1968). Leadership: Psychological aspects. In D.L. Sills (Ed.), International Encyclopedia of the Social Sciences (Vol. 9, pp. 91-101). New York: MacMillan.

Gildersleeve, C. (1978). The international border city: Urban spatial organization in a context of two cultures along the United States-Mexico boundary. Ph.D. dissertation, University of Nebraska.

Grayson, G. W. (1995, September). The Mexican presidency. Paper presented at conference on "Society and Politics: Mexico and the United States", a reciprocal perspective. Colegio de la Frontera, Tijuana, Mexico. Guba, E.G. \& Lincoln, Y.S. (1981). Effective evaluation: San Francisco, CA: Jossey-Bass. Hansen, N. (1983). International cooperation in border regions: An overview and research agenda. International Regional Science Review 8:255-270. Hansen, N. (1985). Border region development and cooperation: Western Europe and the U.S.-Mexico borderlands in comparative perspectives. In $0 . \mathrm{J}$. Martinez (Ed.), Across boundaries: Transborder interaction in comparative perspective. El Paso TX: Texas Western Press. 
Harland, D. (1971). "Social indicators in a future context", paper presented at the Ottawa, Canada, Future Society. November 25,1971 .

Hecksher, C. \& Donnellon, A. (1994). The post-bureacratic organization. New perspectives on organizational change. Sage Publications, Inc.

Heifetz, R.A. \& Sinder, R.M. (1988). Political leadership: Managing the publics problem solving. In R.B. Reich (Ed.) The Power of public ideas (pp. 179-203). Cambridge, MA: Ballinger.

Herzog, L.A. (1986). International boundary cities: The debate on transfrontier planning in two border regions. Herzog, L.A. (1990). Where North meets South: Cities, space, and politics on the U.S. - Mexico border. Center for Mexican American Studies, University of Texas at Austin.

Hettne, B. (1994). The regional factor in the formation of a new world order. In Y. Salamoto, (Ed.), Glebal transformation: Challenge to the state system (pp.134164). United Nations University Press. Tokyo, New York, Paris.

Hirst, P. \& G. Thompson (1996). Globalization in question. Cambridge, CB2 IUR, UK: Polity Press. 
Holmberg, J. \& R. Sandbrook (1992). Sustainable development: What is to be done? In J. Holmberg (Ed.), Making development sustainable: Redefining institutions, policy, and economics (pp. 19-38). International Institute for Environment and Development. Island Press, Washington, D.C.

Hollander, P.E. Offerman, R. L. (1990). Power and leadership in organizations: Relationships in transition. American Psychologist.

House, J.W. (1982). Frontier on the Rio Grande. Oxford: Clarendon Press.

Jamail, M.H. \& Gutierrez, M. (1992). The border guide. Institutions and organizations of the United StatesMexico borderlands. Center for Mexican American

States. University of Texas at Austin.

Jimenez, M.L., Martinez Ornelas, R., Meyer, U., Pena, L., Sheldo, J. (1994). Political institutions. In J. Gerber, (Eds.) Economic orofile of the San DiegoTijuana Region: Characteristics for investment and governance decisions (pp. 19-24).

Institute for Regional Studies of the Californias, San Diego State University. 
Jones, R. (1945) . Boundary making: A handbook for statesmen, treaty editors and boundary comissioners. Washington, DC: Carnegie Endowment for International Peace.

Kiy, R. (1993, March 22). A lesson for San Diego from Cascadia. The San Diego Union-Tribune.

Kolinsky, M. (1981). The nation-state in Western Europe: Erosion from above and below. In L. Tivey, (Ed.), The nation-state: The formation of modern politics (pp. 82-193). Oxford: Martin Robertson.

Iincoln, Y.S. \& Guba, E. G. (1985) . Naturalistic inquiry. Newbury Park, CA: Sage

Lindbloom, C.E. (1959). The science of muddling through. Public Administration Review, 19, 79-88.

Iindbloom, C.E. (1968). The policy-making process.

Englewood Cliffs, NJ: Prentice-Hall.

Lopez, G. \& Clement, N. C. (1996, April). Responding to the new economy: Local development initiatives in the San Diego-Tijuana region. Paper presented at the second InterAmerican Conference of Mayors: "An Emerging Policy Agenda for Local Governments", Miamai, FLA March, J.G., \& Simon, H. (1958). Organizations. New York: Wiley. 
Mathison, S. (1988). Why triangulate? Educational

Researcher, 17, 13-17.

Merriam, S.B. (1988). Case study research in education:

A Qualitative approach. San Francisco, CA: JosseyBass.

Mintzberg, H. (1978). Patterns in strategy formation.

Government Science, 24(9), 934-948.

Modelski, G. (1972). Principles of world politics. New

York: Free Press.

Morgan, G. (1986). Images of organization. Sage

Publications, Inc.

Ojeda, M.G. (1983). The future of relations between Mexico and the United States. In C. W. Reynolds \& C. Tello, (Eds.), U.S.Mexico relations. Economic and social aspects (pp.315-330). Stanford University Press.

Ohmae, K. (1990). The borderless world: Power and strategy in the interlinked economies. New York: Free Press.

Ohmae, K. (1995). The end of the nation state: The rise of regional economies. New York: Free Press.

Patton, M.Q. (1980). Qualitative evaluation methods. Newbury Park, CA: Sage.

Pettigrew, A.M. (1985). Culture and politics in strategy decision making and change. In J.M. Pennings, (Ed.), The strategic decision making in complex organizaions. 
Jossey-Bass, San Erancisco, CA.

Purcell, S. (1975). The Mexican profit-sharing decision:

Politics in an authoritarian regime. Berkeley \& Los

Angeles: University of California Press.

Report of the binational task force on economic developmet and transportation infrastructure, sept. 30, 1993, San Diego, CA

Reynolds, C. (1984). A shift share analysis of regional and sectoral productivity growth in contemporary Mexico and the United States: Implications for economic interdependence. In A. Corona \& L. Gibson, (Eds.), Regional impacts of United States-Mexican economic relations (pp. 71-89). Mexico City: Colegio de Mexico.

Rosener, B.J. (1990, November-December). Ways women lead.

Harvard Business Review.

Rost, J. (1992). Leadership for the twenty-first century. New York: Praeger Publishers.

Sayer, S. (1982). The economic analysis of frontier regions. West European politics 5:64-80.

Schendel, D.E., \& Hoffer, C.W. (Eds.), (1979). Strategic management: $A$ new view of business policy and planning. Little Brown, Boston, Mass. 
Shaw, K.E. (1978). Understanding the curriculum: The approach through case studies. Journal \& Curriculum Studies, 10 (1), 1-17.

Sloan, J., \& West, J. (1976). The role of informal policy making in U.S.-Mexico border cities. The Social Science Quarterly 58:270-282.

Smircich, I. \& Morgan, G. (1982) . Leadership: The management of meaning. The Journal of Applied Behavioral Science, 18 (3), 257-273. Spykman, N.J. (1942). Frontiers, security and international organization. Geographical Review 37:94-105.

Stake, R.E. (1981). Case study methodology: An epistemological advocacy. In W.W. Welsh (Ed.), Case study methodelogy in educational evaluation. Proceed ings of the 1981 Minnesota Evaluation Conference. Minneapolis: Minnesota Research and Evaluation Center. strassoldo, R. (1982). Boundaries in sociological theory: A reassessment. In R. Strassoldo \& G. Delli Zotti (Eds.), cooperation and conflict in border areas (pp. 245-271). Milan: Franco Angeli Editore. Taylor, P.J. (1985). Political geography: World-economy, nation-state and locality. London: Longman. U.S. Census of the Population (1990). 
U. S. Department of Commerce. (1978). Economic problems of the California border region, San Diego County. Washington, DC: Economic Development Administration. Ward, P. (1986). Welfare politics in Mexico: Papering over the cracks. London: Allen \& Unwin.

Wilson, S. (1979). Explorations of the usefulness of case study evaluations. Evaluation Quarterly, 1, 446-459. World Commission of Environment \& Development 1987:40.

Yin, R.K. (1984). Case study research: Design and methods. Newbury Park, CA: Sage.

Yoshikazu, S. (1994). Editors introduction. In S. Yoshikazu (Ed.), Global transformation: Challenges to the state system (pp. 1-14). United Nations University Press.

Zaikai, (1983). Nissan Motor Co. Ltd., At home and abroad. Japaneeds (Multilingua), London. 
Carta de Acuerdo Entre las Ciudades de Tijuana y San Diego en el Campo de la Planificación y Coordinación Binacional
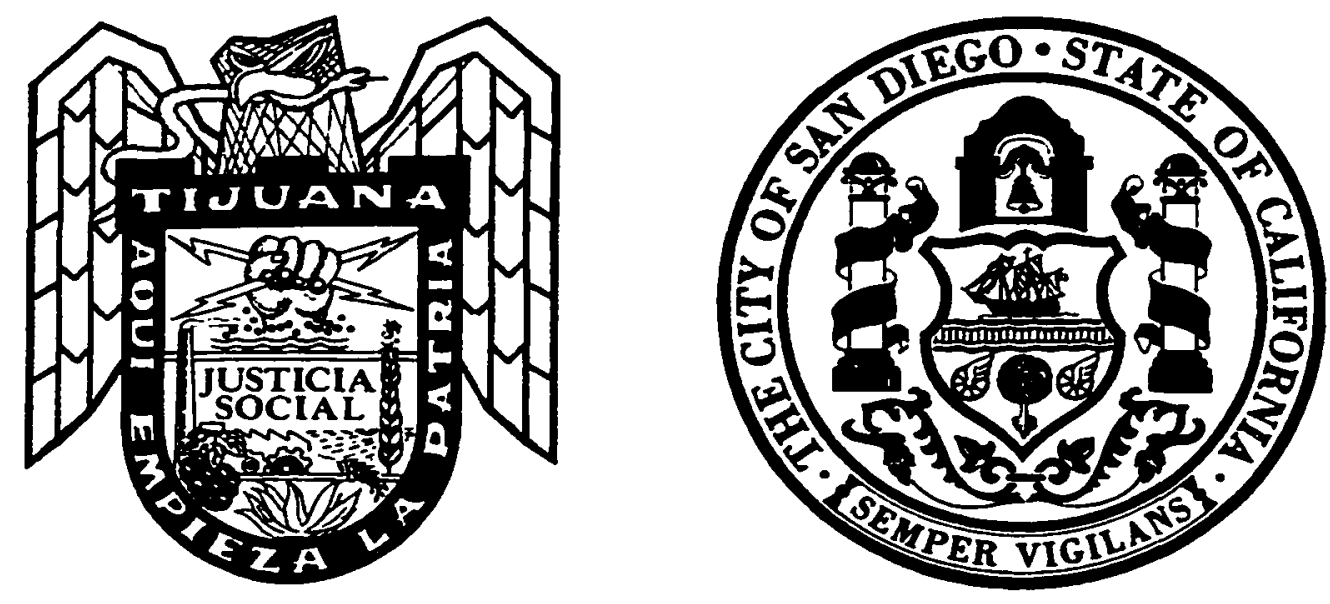

Letter of Agreement between the City of Tijuana and the City of San Diego in the field of binational planning and coordination.

Abril 14, 1993

April 14, 1993 
CONSIDERANDO que los gobiernos municipales de Tijuana y San Diego están interesados en la cooperación en asuntos binacionales;

CONSIDERANDO que los representantes de ambos gobiernos se vienen reuniendo regularmente para discutir asuntos fronterizos y regionales;

CONSIDERANDO que las partes reconocen la existencia de un interés común en el intercambio de información y trabajos de investigación, y en particular con respecto a asuntos relacionados con la planificación del uso del suelo, manejo de desechos, las artes y la cultura, turismo, manejo de aguas, y otros que afectan la frontera común;

CONSIDERANDO que las partes proyectan establecer arreglos para facilitar el intercambio de información y otras actividades en materia de asuntos comunes.

\section{LAS PARTES HAN ACCORDADO LO SIGUIENTE:}

\section{Comité Binacional de Planeación y Coordinación}

a. Por la presente se establece un Comité Binacional de Planeación y Coordinación. Este Comité será presidido por losalcaldes de Tijuana y San Diego. El Propósito de dicho Comité es el de facilitar el intercambio de información y otros medios de cooperación que se establezcan de conformidad con el presente acuerdo, entre las ciudades de San Diego y Tijuana.

b. El Comité Binacional de Planeación y Coordinación estará integrado por ocho miembros. Cada alcalde nombrará cuatro miembros y Los alcaldes serán los Copresidentes.

c. El Administrador General de la ciudad de San Diego y el Director de Planeación de Desarrollo Urbano y Ecologia de Tijuana también formarán parte de este Comité. Estos últimos mantendrán estrechas relaciones y serán responsables de facilitar la labor del Comité Binacional de Planeación y Coordinación.

d. El Comité Binacional de Planeación y Coordinación se reunirá mensualmente.

2. Grupos Conjuntos de Trabajo

a. El Comité Binacional de Planeación y Coordinación podrá establecer Grupos Conjuntos de Trabajo para realizar las tareas que les encomiende el Comité.

b. La Partes reconocen que las autoridades estatales, municipales y otras autoridades locales de ambos lados estarán interesadas y deberán participar en actividades cooperativas a realizarse bajo el presente Acuerdo. Con el objeto de establecer Grupos de Trabajo eficaces y equilibrados, los alcaldes o sus designados, previa consulta, nombrarán los respectivos miembros de un Grupo de Trabajo. Los Copresidentes podrán invitar a representantes de los organismos federales, representantes de gobiernos estatales o municipales,
WHEREAS, the City Governments of Tijuana and San Diego are interested in increased border issues cooperation;

WHEREAS, representatives from both governments have been meeting regularly to discuss border issues;

WHEREAS, the parties recognize a mutual interest in exchanging information and research related to land planning, waste management, arts and cultural, tourism, water and waste water, parks and recreation, economic development, urban planning, and other issues affecting their common border;

WHEREAS, the parties intend to establish arrangements that will facilitate the sharing of information and other cooperative efforts of mutual concern.

\section{THE PARTIES HAVE AGREED AS FOLLOWS:}

1. Binational Planning \& Coordinating Committee

a. A Binational Planning \& Coordinating Committee is hereby established. This committee shall be chaired by the Mayors of Tijuana and San Diego. The purpose of this Committee is to facilitate the exchange of information, and enhance cooperation between Tijuana and San Diego.

b. The Binational Planning \& Coordinating Committee will have eight members. The Mayors of each city will designate four members and the Mayors will serve as the co-chair persons.

c. The City Manager of San Diego and the Director of Urban Planning and Ecology of Tijuana will serve on the committee. They will maintain close communication and be responsible for facilitating the work of the Committee.

d. The Binational Planning \& Coordinating Committee will meet monthly.

\section{Joint Working Groups}

a. The Binational Planning \& Coordinating Committee may establish Joint Working Groups to carry out tasks assigned by the Committee.

b. The parties recognize that state, municipal and other local authorities of both sides of the border will be interested in and should be involved in cooperative action under this agreement. In order to establish balanced and effective working groups, the Mayors, or their designees, will consult before appointing the respective members of a working group. The Mayors may invite representatives of federal agencies, state organizations, members of private organizations or individual private citizens to participate in a working group. 


\section{BINATIONAL PLANNING AND COORDNATION COMMITTEE COMITE BINACIONAL DE PLANEACION Y COORDNNACION \\ San Diego / Tijuana}

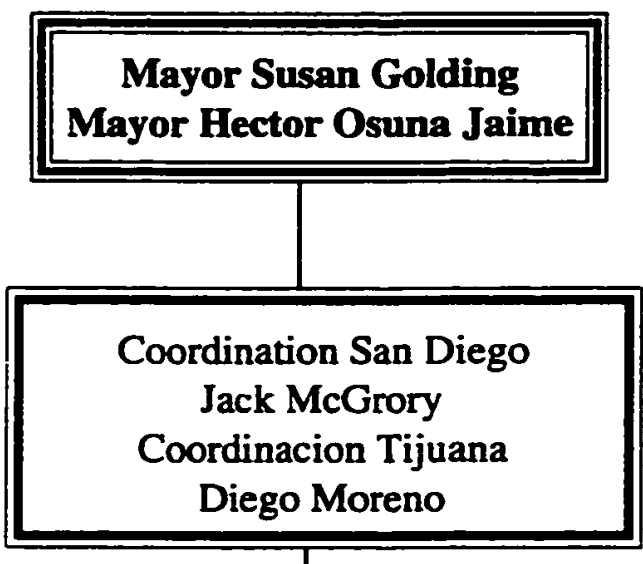

Libraries, Arts, Recreation \& Culture Bibliotecas, Artes, Recreacion y Cultura

Luis Herrera San Diego Luis Bustamante Tijuana

- Library

- Culture

- Sports

- Bibliotecas

- Cultura

- Deporte
Public Works and Services Obras y Servicios Publicos San Diego Zeferino Sanchez Tijuana
- Transport

- Public Works

- Technology Transfer

- Transporte

- Obras Publicas

- Transferencia de Technologia
Public Safety

Seguridad Publica

Jerry Sanders San Diego

Lic. Victor Manuel Vasquez Tijuana
Planning and Land Use Planeacion Urbana

Ernest Freeman San Diego

Diego Moreno Tijuana
- Police Service

- Emergency Management

- Fire Department

- Policia

- Proteccion Civil

- Bomberos
- Planning \& Land Use

- Planeacion Urbana

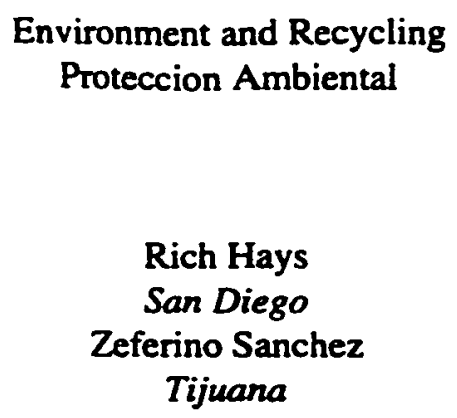

Economic Development

Desarrollo Economico

Kurt Chilcott San Diego

Luis Bustamante Tijuana 
miembros de organizaciones privadas, o a ciudadanos particulares, a participar en un Grupo de Trabajo.

\section{Programas y Proyectos en Régimen Cooperativo}

a. El Comité Binacional de Planeación y Coordinación seleccionará los programas y proyectos de cooperación a emprenderse de conformidad con el presente Acuerdo. Cada uno de los programas y proyectos se definirá detalladamente, incluyendo el alcance y la prioridad de la tarea a realizar, un programa para su conclusión, asi como la composición del Grupo de Trabajo encargado de la acción.

b. Se Podrá establecer un programa o proyecto en cooperación para llevar a cabo cualquier actividad acordada por el Comité Binacional de Planeación y Coordinación.

El Comité Binacional de Planeación y Coordinación será responsable de la administración de los programas y proyectos que se lleven a cabo bajo los términos de este Acuerdo. Cada uno de los Grupos de Trabajo será responsable de mantener informado al Comité Binacional de Planeación y Coordinación sobre los programas o proyectos bajo su dirección y solicitarán instrucciones del Comité cuando sea necesario.

4. Los dos ciudades han acordado cooperar en los siguientes campos:

- Protección Ambiental

- Planificación Municipal y Regional

- Desarrollo Económico

- Servicios de Policía

- Servicios de Bomberos

- Acueductos y Alcantarillado

- Servicios de Biblioteca

- Parques y Recreación

- Transferencia de Tecnología

- Manejo de Desechos y Reciclaje

- Protección Civil

5. El Comité se reunirá immediatamente y concentrará su labor en el plan de trabajo adjunto.
3. Cooperative Programs and Projects

a. The Binational Planning \& Coordinating Committee will select all programs and projects for cooperative action under this Agreement. Each program or project will be defined in detail, including the scope and priority of effort, a schedule for completion, and membership of any working group assigned responsibility for the action.

b. A cooperative program or project may be established to carry out any activity agreed by the Binational Planning \& Coordinating Committee.

The Binational Planning \& Coordinating Committee will be responsible for the general management of programs and projects undertaken pursuant to this Agreement. Each working group assigned responsibility for a project or program will keep the Binational Planning \& Coordinating Committee fully informed of its work and will seek additional guidance from the committee as necessary.

4. The Two Cities Agreed to Cooperate in the Following Areas:

- Municipal and Regional Planning

- Economic Development

- Police Services

- Fire Services

- Water and Sewage Systems

- Library

- Parks and Recreation

- Technology Transfer

- Waste Disposal and Recycling

- Environmental Protection

- Emergency Management

5. The Committee Will Begin to Work Immediately to Focus on the Attached Work Plan.

\author{
Héctor Osuna Jaime \\ Alcalde de Tijuana \\ Mayor of Tijuana
}

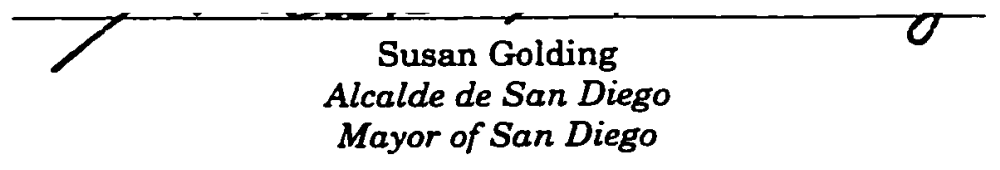




\section{U.S.-Mexico Border Region}

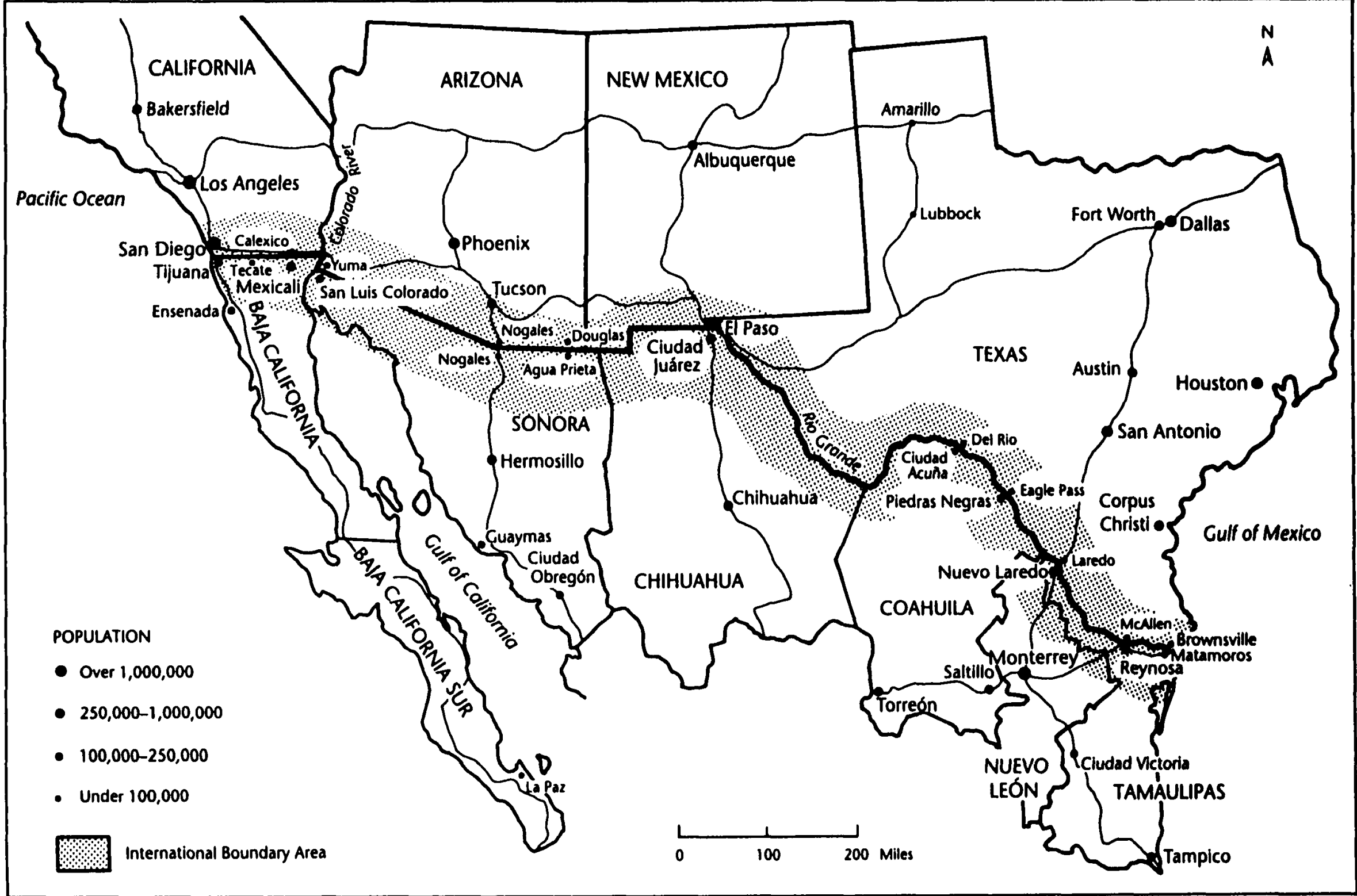

Reprinted, by permission, from Lawrence A. Herzog, Where North Meets South: Cities, Space, and Politics on the U.S.-Mexico Border (Austin: Center for Mexican American Studies, University of Texas at Austin, 1990), 34. 


\section{APPENDIX C}

Transborder Economic Development

A Collaborative Partnership:

The San Diego-Tijuana Experience

Piedad Garcia

\section{General Questions}

1. In your opinion what is the purpose of the BPCC?

2. Can you please describe what is the role and function of the BPCC?

3. What kind of structure does the BPCC have?

4. What is the decision making process of the BPCC.

5. What process does the BPCC carry out to fulfill its leadership role in the context of its function?

6. Does the BPCC or do you perceive a need for a regional strategic plan?

7. In your opinion do you see a need to restructure the BPCC and does the membership perceive this need?

8. Do you have any other comments?

Work Group Questions

1. How long have you been a member of the BPCC.

2. What is your role in the BPCC?

3. How often does your work group meet?

4. How does your work group decide on what projects to focus on?

5. In you opinion does the BPCC fulfill its purpose?

6/10 Per: questions 
Desarrol10 Economico Transfronterizo

Una Asociacion Colaborativa:

La experiencia de Tijuana-San Diego

Piedad Garcia

\section{Preguntas Generales}

1. En su opinion cual es el proposito del CBPC?

2. Me puede describir como funciona el CBPC?

3. Que tipo de estructura tiene el CBPC

4. Cual es el proceso de toma de decisiones del CBPC?

5. Que procesos lleva a cabo el CBPC en su funcion de liderazgo en el contexto de su funcion?

6. El CBPC o usted percive la necesidad de realizar un plan estrategico regional.

7. En su opinion ve usted la necesidad de restructurar el CBPC? Los miembros perciven esta necesidad?

8. Tiene algun otro comentario?

\section{Preguntas Adicionales}

1. Hace cuanto tiempo usted es miembro del CBPC?

2. Que papel desempena usted en el BPCC?

3. Que tan frecuente se reune su grupo?

4. Como actua el CBPC para llevar a cabo su proposito? 
APPENDIX D

April 7, 1997

\author{
Jack McGrory \\ City Manager \\ City of San Diego \\ 202 C street, 11th Floor \\ San Diego, CA 92101
}

Mr. Megrory

In partial fulfillment for my doctoral degree in Leadership and Education in the School of Education at the University of San Diego, I am proposing a research study of the Binational Planning and Coordinating Committee, (BPCC). Mayor Susan Golding Major Hector Osuna Jaime established this entity in 1993 pursuant to the Letter of Agreement between the City of Tijuana and the City of San Diego. I am pursuing this area of study in light of the interest that our transborder regions represent today. The internationalization of the local market economy, the implementation of the North American Free Trade Agreement, and the mutual interests that San Diego and Tijuana share in the future of sustainable economic development are dimensions that set the context for the study of the BPCC.

The study that I am proposing uses a qualitative method that is descriptive and thus examines the BPCC as an entity, its structure, and its decision making processes in transborder collaboration. The need for a policy making entity will be explored as well. With your approval, I would like to interview you and your counterpart as the Coordinators of the BPCC, and the twelve co-chairs of the work groups. There will be a maximum of two interviews, one hour each in length. I also intend to attend the BPCC monthly meetings. Review of archival records, such as public documents, reports, and minutes of meetings will also be used. The results of the data analysis will be presented as group data and in narrative form. In order to preserve confidentiality and anonymity names will not be disclosed without consent required by law.

It is my hope that this research study yields information to benefit decision makers on both sides of the border in the area 
of planning sustainable economic development for the transborder region. The study can also increase understanding about the current structure of the BPCC, its leadership, and explore the need for alternative structures which can facilitate collaborative economic development strategies for the border region.

I appreciate and thank you beforehand for taking the time to consider and approve this research study of the BPCC. I will be contacting your office in the next week to further clarify the research proposal and answer any questions that you may have. I will also forward this letter of introduction to the City Manager of Tijuana.

Sincerely,

Piedad Garcia, LCSW

Doctoral Candidate

School of Education

University of San Diego

cc: Gonzalo Lopez 
Abril 7, 1997

Ing. Adolfo Guerrero Camacho Coordinador de Direcciones Palacio De Gobierno Municipal Av. Independencia y Paseo Tijuana Zona Urbana Rio, Tijuana Baja California, 22320 Mexico

Ing. Adolfo Guerrero Camacho

Como prerequisito para el programa de Doctorado en Liderazgo y Educacion de la Universidad de San Diego, (USD) estoy proponiendo un estudio de investigacion cualitativo sobre el Comite Binacional de Planeacion y Coordinacion, (CBPC).

El ex-presidente municipal, Sr. Hector Osuna Jaime y la alcaldesa de San Diego, Susan Golding establecieron esta entidad en 1993 en una Carta de Acuerdo entre el municipio de Tijuana y la ciudad de San Diego. Mi interes en esta area de estudio nace de la importancia que representa esta region transfronteriza en la actualidad.

La internacionalizacion de las economias locales, la implementacion del Tratado de Libre Comercio (TLC) y el interes mutuo que Tijuana y San Diego comparten en el desarrollo sustentable de la region, determinan el contexto de este estudio del CBPC.

El estudio que propongo utiliza una metodologia cualitativa, descriptiva y por lo tanto analiza el CBPC como una entidad, su estructura y su proceso de toma de decisiones en la colaboracion transfronteriza. La necesidad de una entidad que desarrolle politicas de accion tambien sera explorada. 
Con su aprobacion, me gustaria entrevistarlo, asi como tambien al Coordinador de la Ciudad de San Diego y a los 12 Jefes de los equipos de trabajo del CBPC.

Habra un maximo de 2 entrevistas de una hora cada una. Tambien participare como observadora a las juntas mensuales del CBPC. Este estudio requiere tambien revisar los documentos de dominio publico asi como reportes y minutas de las juntas de trabajo. Los resultados del estudio seran presentados en un formato narrativo. Para conservar la confidencialidad y anonimidad de los integrantes de CBPC, los nombres no seran utilizados sin el consentimiento requerido por la ley. El nombre de la entidad sera usado en los resultados de este estudio.

Mi expectativa es que este estudio proporcione informacion que beneficie a quienes toman decisiones en ambos lados de la frontera, en el area de desarrollo sustentable de esta region transfronteriza. El estudio tambien puede ayudar al entendimiento de la estructura actual del CBPC y su liderazgo. Ademas se va a explorar la posibilidad de estructuras alternativas que puedan facilitar la colaboracion en el desarrollo economico y su planeacion.

Quisiera de antemano agradecer su consideracion a la aprobacion de este estudio. Estare en contacto con su oficina en los dias venideros para aclarar con mas detalle la propuesta de estudio $y$ responder a cualquier pregunta que pudiese tener. Esta propuesta tambien sera enviada al Sr. Jack McGrory en12 San Diego.

Piedad Garcia, LCSW

Facultad de Educacion

Universidad de San Diego

cc: Gonzalo Lopez 


\section{The City of San Diego}

April 22, 1997

Piedad Garcia

3744 Amold Ave. \#2

San Diego, CA 92104

Dear Ms. Garcia:

I am in receipt of your correspondence requesting permission to conduct a qualitative study of the Binational Planning and Coordinating Committee, (BPCC.) I understand that you are undertaking this research in partial fulfillment of your doctorate degree at the University of San Diego. I am granting you consent to conduct this study and to utilize the name of the BPCC in the publication of the results in your dissertation.

I hope that the study of this entity will provide us with insight into binational collaborative relationships in the San Diego/Tijuana region. If you have any questions, please feel free to contact Gonzalo Lopez at 236-6551.

Sincerely,

Jé́ck McGrory,

City Manager

cc: Cruz Gonzalez

Gonzalo Lopez

Mary Abascal-Hilderbrand 


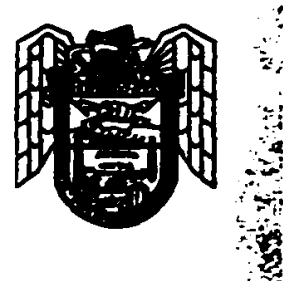

IYUNTAMIENTO NSTTTUCIONAL TUUANA, B.C.
DEPENDENCLA:

SECCION: COORDRACION DE DIRECCIONES NUMERO DEL OFICIO:

EXPEDIENTE:

COMITÉ BINACIONAL

ASUNTO:

El que se indica:ión:

Tijuana, B.Cfa. a 12 de junio de 1997

“Tijuana Compromiso de Todos"

\title{
C LICENCIADA PIEDAD GARCIA SAN DIEGO, CALIFORNIA \\ Presente.
}

He recibido su correspondencia solicitando el consentimiento de la administración municipal para llevar a cabo un estudio cualitativo sobre el Comité Binacional de Planeación y Coordinación CBPC. Entiendo que este está auspiciado por la Universidad de San Diego y es un pre-requisito para la obtención de su doctorado en la facultad de Educación. Estoy de acuerdo con este fin y la autorizo para utilizar el nombre de este comité en la publicación de los resultados de su disertación.

Espero que este estudio aporte información sobre las relaciones de estrecha colaboración entre las ciudades de Tijuana y San Diego.

Sin otro particular y deseandole éxito en su empeño.

\author{
A te n t a m e nte \\ SUFRAGIO EFECTIVO. NO REELECCION \\ ELCOORDINADQR DE DIRECCIONES
}

ING. ADOLFO GUERRERO CAMACHO

AGC/rgu.

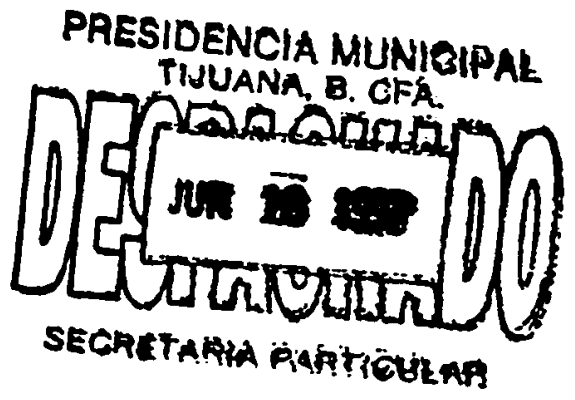

Palacio de Gobiemo Municipal. A ve. Independencia y Paseo Tijuana s/n Zona Urbana Rio Tijuana. B.C. Tel./Fax: 83-53-68 


\section{TRANSLATION OF LETTER FROM TIUUANA'S CITY MANAGER}

12, June , 1997

Tijuana, B.C.

I am in receipt of your correspondence requesting permission from the municipal administration to conduct a qualitative study about the Binational Planning and Coordinating Committee, (BPCC). I understand that this study is being sponsored by the University of San Diego and is a prerequisite for your doctoral candidacy in the School of Education. I am in agreement and grant you permission to use the name of this committee in the publication of the results of your dissertation.

I hope that this study provides information about the close collaborative relationships between the cities of Tijuana and San Diego.

I wish you success in your effort.

Attentively

The City Manager

Ing. Adolfo Guerrero Camacho 
APPENDIX F

July 7, 1997

$\mathbf{x}$

$\mathbf{x}$

$\mathbf{x}$

$\mathbf{x}$

Mr. $\mathbf{x}$

In partial fulfillment for my doctoral degree in Leadership Studies from the School of Education at the University of San Diego, I am conducting a research study of the Binational Planning and Coordinating Committee, (BPCC). The City Mangers of San Diego, Jack MCGrory and Lic. Adolfo Guerrero Camacho from Tijuana have given me the permission to carry out this study. I am pursuing this area of study in light of the interests that our transborder regions represent today. The internationalization of the local market economy, the implementation of the North American Free Trade Agreement, and the mutual interests that San Diego and Tijuana share in the future of sustainable economic development are dimensions that set the context for this study of the BPCC.

The study that I will be conducting uses a qualitative methodology that is descriptive and thus examines the BPCC as an entity, its structure, and its decision making processes in transborder collaboration. The need for a policy making entity will be explored as well. The qualitative methods I will be using in this study include interviews of the subjects and thus I would like to interview you and your counterpart as the co-chairs of the work groups and the Coordinators of the BPCC. There will be a maximum of two interviews, one hour each in length.

I will also be attending the BPCC monthly meetings and will be reviewing archival records, such as public documents, reports, 
and minutes of meetings. The results of the data analysis will be presented in narrative form in order to preserve confidentiality and anonymity of the participants. The name of the BPCC will be used in the publication of the data results.

It is my hope that this research study yields information to benefit decision-makers on both sides of the border in the area of planning sustainable economic development for the transborder region. The study can also increase understanding about the current structure of the BPCC, its leadership, and explore the need for alternative structures which can facilitate collaborative economic development strategies for the border region.

I appreciate your consideration and I thank you beforehand for taking the time to participate in this research study of the BPCC. I will be contacting your office in the next week to further clarify the research study and set an appointment for the first interview at your convenience.

Sincerely,

Piedad Garcia LCSW

Doctoral Candidate

School of Education

University of San Diego

CC: Gonzalo Lopez 


\section{APPENDIX F}

Julio 7, 1997

$\mathbf{x}$
$\mathbf{x}$
$\mathbf{x}$
$\mathbf{x}$

Sr.

Como prerequisito para el programa de Doctorado en Liderazgo en la facultad de Educacion de la Universidad de San Diego, (USD) voy a conducir un estudio cualitativo sobre el Comite Binacional de Planeacion y Coordinacion, (CBPC). El Director de Direcciones de Tijuana, Lic. Adolfo Guerrero Camacho y el Sr. Jack McGrory, Director de Gestiones de la ciudad de San Diego han otorgado el permiso para llevar a cabo este estudio como Coordinadores de la CBPC. Mi interes en esta area de estudio nace de la importancia que representa esta region transfronteriza en la actualidad.

La internacionalizacion de las economias locales, la implementacion del Tratado de Libre Comercio (TLC) y el interes mutuo que Tijuana y San Diego comparten en el desarrollo sustentable de la region, determinan el contexto de este estudio del CBPC.

El estudio que voy a realizar utiliza una metodologia cualitativa, descriptiva y por lo tanto analizara el CBPC como entidad, su estructura y su proceso de toma de decisiones en la colaboracion transfronteriza. La necesidad de una entidad que desarrolle politicas de accion tambien sera explorada.

Los metodos que voy a utilisar incluye entrevistarlo(a) a usted con su aprobacion, entrevistar los otros jefes de los equipos de trabajo, y a los dos Coordinadores de la CBPC. Habra un maximo de 
2 entrevistas de una hora cada una. Tambien participare como observadora en las juntas mensuales del CBPC.

Este estudio requiere tambien revisar los documentos de dominio publico asi como reportes $y$ minutas de las juntas de trabajo. Los resultados del estudio seran presentados como datos integrados $y$ en un formato narrativo. Para conservar la confidencialidad $y$ anonimidad de los integrantes del CBPC, los nombres no seran utilizados sin el consentimiento requerido por la ley. El nombre de la CBPC sera utilizado en la publicacion de los datos.

Mi expectativa es que este estudio proporcione informacion que beneficie a quienes toman decisiones en ambos lados de la frontera, en el area de desarrollo sustentable de esta region transfronteriza. El estudio tambien puede ayudar al entendimiento de la estructura actual del CBPC y su liderazgo. Ademas se va a explorar la posibilidad de estructuras alternativas que puedan facilitar la colaboracion en el desarrollo economico y su planeacion.

Quisiera de antemano agradecer su participacion en este estudio. Estare en contacto con su oficina en los dias venideros para aclarar cualquier pregunta que pudiese tener y hacer la cita para la primera entrevista.

Sinceramente

Piedad Garcia, LCSW

Candidata al Doctorado

Universidad de San Diego

cc: Gonzalo Lopez 


\section{APPENDIX G \\ University of San Diego \\ School of Education \\ CONSENT TO ACT AS A RESEARCA SUBJECT}

Piedad Garcia is conducting a research study of the Binational Planning and Coordination Committee, (BPCC). I have been selected to participate in this study, and I understand that I will be interviewed by Piedad Garcia in my business office. I am aware that the Coordinators of the BPCC, Jack MCGrory and Lic. Adolfo Guerrero Camacho have agreed to participate in this study and I am aware that the name of the BPCC will be used in this study.

This data collection will take approximately two hours of my time, a maximum of two interviews will be conducted over a six month period. I understand that I may refuse to participate or withdraw at any point in time without repercussions. Ms Garcia has explained to me the potential risks that may result from this study. These may include the possibility of my identity being infer by the results and there might be some unwelcome publicity.

However, I understand that the risks will be minimized by: 1 . My research records will be kept completely confidential. 2. My identity will not be disclosed without consent. 3. To preserve my anonimity data will be presented in narrative form 4. No direct quotes will be used and 5. I will be given the opportunity to review the research assumptions before they are finalized.

Piedad Garcia has explained this study to me fully and answered my questions. If I have further questions or researchrelated concerns, I can reach Dr. Mary Abascal-Hildebrand at (510) 560-6768. I understand that I will not be reimbursed for my participation in the interviews.

There are no other binding agreements, written or verbal, related to this study beyond that expressed on this consent form. Experimental Subjects Bill of Rights".

I, the undersigned, understand the above explanations and on that basis, I give consent to my voluntary participation in this research.

Signature of Subject $\quad$ Date

Location Date

Signature of Researcher Date

$7 / 7$ research 


\section{APPENDIX G}

\section{Universidad de San Diego}

Facultad de Educacion

consentimiento de Informe como Sujeto de Investigacion

Piedad Garcia esta llevando a cabo un estudio sobre el Comite Binacional de Planeacion $y$ Coordinacion, CBPC. Yo he sido seleccionado(a) para participar en este estudio $Y$ entiendo que sere entrevistado(a) por Riedad Garcia en mi oficina. Estoy consciente que los Coordinadores de el CBPC Lic. Adolfo Guerrero Camacho $y$ el Sr. Jack McGrory han aprovado oficialmente este estudio $y$ entiendo que el nombre de esta entidad sera revelado en los resultados.

Habra un maximo de dos entreyistas de aproximadamente una bera cada una $y$ el estudio tomara seis meses. Entiendo que puedo rehusar mi participacion sin ninguna repercusion. La Senorita Garcia me ha explicado los riesgos que pueden presentarse con los resultados de este estudio. Estos pueden incluir la posibilidad de que mi identidad se pueda inferir en los resultados $y$ puede haber publicidad negativa.

No obstante, yo entiendo que estos riesgos seran reducidos por los siguientes hechos: 1) Mi archivo es confidencial 2) $M i$ identidad no sera revelada sin mi consentimiento 3) Para preservar mi anonimidad los datos seran presentados en forma narrativa 4) Referencias directas no seran usadas 5) $\mathrm{Mi}$ entrevista sera conducida en español y sera traducida al ingles 6) Revisare los resultados de mi entrevista.

Riedad Garcia me ha explicado este estudio completamente $y$ ha contestado mis preguntas. Si tengo alguna otra pregunta relacionada con este estudio, puedo comunicarme con la Dra. Mary Abascal-Hilderbrand al (619) 560-6768. Entiendo que no habra ninguna recompensa por mi participacion en las entrevistas.

No existe de mi parte ningun acuerdo legal, escrito o verbal, relacionado con este estudio, fuera de lo expresado en este consentimiento basado en los Derechos de Sujetos en Experimentos.

Yo, , entiendo las explicaciones dadas y bajo dichas' explicacioness, doy mi consentimiento de participacion voluntaria en este estudio.

Firma del sujeto $\quad$ Fecha

Direccion $\quad$ Fecha

Firma de la Investigadora

$7 / 7$ consent

Fecha 


\section{Agreement for}

Binational Cooperation

between the cities of

San Diego and Tijuana

1996-1997

\author{
Acuerdo de \\ Cooperación \\ Binacional entre las \\ ciudades de Tijuana y \\ San Diego 1996-1997
}
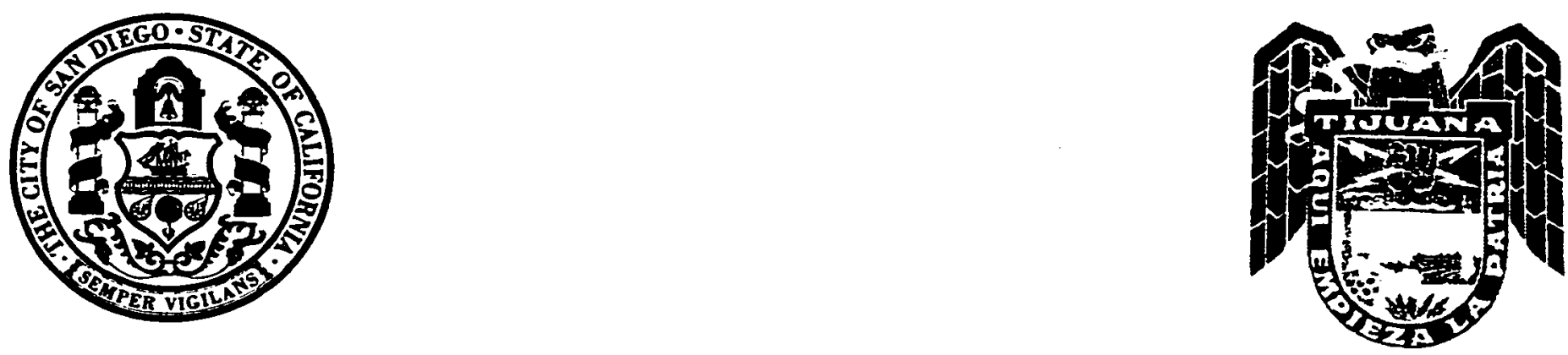


\section{APPENDIX H AGREEMENT FOR BINATIONAL COOPERATION BETWEEN THE CITIES OF SAN DIEGO AND TIJUANA 1996-1997}

We, the Mayors of San Diego and Tijuana, establish on this day, July 31 st, nineteen-ninety six, the Agreement for Binational Cooperation. We pledge to continue and expand cordial and mutually beneficial ties between the Cities of San Diego and Tijuana through the Binational Planning and Coordination Committee in the areas of;

- Libraries, Arts, Recreation and Culture

- Public Works and Service

- Public Safety

- Planning and Land Use

- Environment and Recycling

- Economic Development

With this agreement we ratify the attached work plans as the basis for binational cooperation in the years 1996-1997.

Susan Golding

Mayor of San Diego

Alcalde de San Diego
Jose Guadalupe Osuna Millán

Alcalde de Tijuana

Mayor of Tijuana 


\section{Public Safety Sub-committee}

Project

Ride-along Exchange

24-hour emergency/natural disaster communication link (in conjunction with the Tectnology

Working Group)

San Ysidro Port of Entry

Security Program

Border Crime Conference

Flood Warning Signage

Emergency Flood Response

Fire-fighter Training
Details

Collect data and evaluate behavior focusing on gang activity in San Diego and visitors to Tijuana.

Implement communication link and contact protocol using a hot-line, duty pagers, Internet communications, two-way radio and fax. Create emergency public safety directory.

Assign police on both sides of the border to formulate measures to improve safery.

Form annual conference of workshops and seminars to address bi-national public safety and emergency management issues.

Install bilingual flood warning signs on both sides of the border fence in the area adjacent to the Tijuana River Valley

Program during the flood season for emergency vehicles to aid stranded US citizens on the Tijuana River Valley South Bank.

Continue San Diego Fire Department programs to train/educate Mexican personnel. Add courses on training techniques in Hazmat, Fire Safety and Fire Prevention courses.

\section{Libraries, Arts, Recreation \& Culture Sub-committee \\ Project}

Artist Exchange

School Field Trips Exchange

Library Staff Exchanges

Library Seminar Series

International Sports Tournaments
Sponsor the formal exchange of professional artists. The project will begin the Summer of 1996 and be an integral aspect of the IN-SITE 1997 Arts Festival. Coordinate with public schools in both Tijuana and San Diego.

Sponsor series of field trips for San Diego and Tijuana public schools to area museums and cultural centers.

Sponsor library staff exchange at public libraries in Tijuana and San Diego to introduce staff to library activity programming techniques.

Sponsor library staff exchange at public libraries in Tijuana and San Diego to introduce staff to a variety of methods, traditions and programs.

Sponsor bi-national sporting events in competitive running, soccer and basketball. Staff members from the San Diego and Tijuana Parks and Recreation Departments will target youth ages six (6) to sixteen (16). 


\section{Public Works and Services Sub-committee}

Project

Details

Surplus Equipment Sale

Identify and assess surplus equipment available for sale by the City of San Diego to the City of Tijuana. Equipment is to be transferred at no less than fair market value.

Disaster Aid

Provide heavy equipment, operators and support services as needed during a major disaster. Facilitate the movement of equipment as needed across the border to assist in clean-up and emergency response.

Educational Exchange

Create interchange between senior staff of Traffic Engineering. Parking Management. Equipment Maintenance and Street Maintenance departments to share information on policies, procedures and relevant technologies.

\section{Environment and Recycling Sub-committee \\ Project \\ Details}

Environmental Exchange

Codes/Regulation Exchange

"Managing Waste in the Border

Region"

Environmental/Recycling

Waste WiSe Program

SD/TJ Binational Recycling

Market Development Zone

Continue to exchange pertinent municipal, state and federal regulations regarding solid waste management.

Continue to hold annual joint workshop.

Waste WiSe focuses, on waste reduction and pollution prevention in the industrial sections of both Otay Mesa and Trjuana. It will also provide data for regional waste management planning. Critical steps include three sessions on waste characterization/waste prevention/recycling assessments (two completed). Tijuana landfill waste composition study (completed), waste assessments at 35-60 TJ/Otay Mesa maquiladora facilities. and the launch of the Border Waste Net. The Border Waste Net will be a cross-border materials exchange available in traditional and Internet forms.

Project currently in progress. The project involves the investigation of the formal and informal recycling industry in TJ and SD, research on customs regulations regarding recyclable materials and, finally, a feasibility study on forming a parallel Recycling Market Development Zone in Tijuana.

\section{Economic Development Sub-committee Project Details}

Binational Economic

Development Forum

Cluster Development Plan

Project San Ysidro Gateway/

Puerta Mexico (in conjunction with

Planning Sub-committee)

Joint Tourism Promotion
Bi-annual forum for discussion and proposal of plans on binational economic development.

Design and implement a plan to promote the development of bi-national enterprises in the core clusters of telecommunications, environmental sciences, electronics manufacturing and tourism.

Implement project to improve transportation, image, land use planning, infrastructure development with community involvement in the area surrounding the San Ysidro Border Crossing.

Form working group with CONVIS and Tijuana authorities to develop joint tourism publicity and destination promotion. 
Binational Production Marketing/

Development
Coordinate with the Otay Mesa Chamber of Commerce and the San Diego/ Tijuana Economic Development Corporations to form specific marketing and business expansion/retention initiatives.

\section{Planning and Land Use Sub-committee}

Project Details

Information Exchange

Data Generation

San Ysidro Gateway

Project/Puerta Mexico

(in conjunction with Economic

Development Subcommitree)
Exchange of information and coordination on planning in the San Diegol Tijuana border region.

Creation and maintenance of a geographical and demographic data base

Design project to improve transportation, image. land use planning. infrastructure development and community involvement in the area surrounding the San Ysidro Border Crossing

\section{Technology Joint Working Group}

Project

Inter-connect Networks

Establish common mail and

network applications

Video-conferencing

Explore phone system

Binational Committee Home Page
Details

Inter-connect the Mayors, City Managers and Department Directors of San Diego and Tijuana for exchange of information, video-conferencing and electronic mail.

Implement the software standard of the City of San Diego on the Tijuana network to ensure compatibility for electronic mail, documents and scheduling information.

Install and activate Video-conferencing capability for the San Diego and Tijuana Mayors and City Managers. Ensure a secure and reliable communications link.

Determine the regulatory and technical feasibility of linking the San Diego and Tijuana City phone networks to achieve cost savings and improvement in reliability.

Develop a home page for the Binational Commitee. available in both Spanish and English. The page will feature the Committee's purpose, projects and accomplishments, as well as information on Binational Commitree events.

\section{Border Transport Joint Working Group}

Project

Liaison with CA/BC - BTTAC
Details

Ensure representation of San Diego and Tijuana interests in planned and effective development of border infrastructure on the California/Baja California Bi-State Transportation Technical Advisory Committee. 


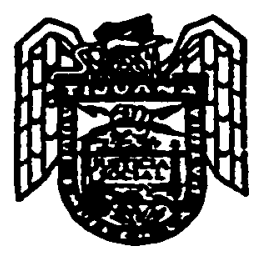

\section{SAN DIEGO - TIJUANA \\ Binational Planning Program}

\section{MANAGERS REPORT}

DATE ISSUED: June 25, 1997

REPORT NO. P-97-110

ATTENTION: $\quad$ Land Use and Housing (LU\&H) Committee, Agenda of July 2, 1997

SUBJECT: $\quad$ Preparation of Binational Plan for the Area of Influence of The San Ysidro/Tijuana Port of Entry.'

\section{SUMMARY}

Issue(s)=

1. Should the LU\& H Committee direct San Diego staff to collaborate with staff from Tijuana in the preparation of a binational plan for the area surrounding the San Ysidro/Tijuana Port of Entry?

2. Should City of San Diego staff proceed to develop with City of Tijuana staff a joint strategy, work program and schedule describing the approach to be utilized in preparing the comprehensive binational plan?

3. Should the City of San Diego seek State and Federal funding to supplement local resources for the binational planning process?

Manager's Recommendation(s) and Recommendation(s) from the Tijuana City Manager - Direct staff to pursue 1 - 3 above.

Community Planning Group Recommendation - The San Ysidro Community Planning Group and the San Ysidro Redevelopment Project Area Committee support this effort and their participation in the planning process.

Other Recommendations - On June 4, 1997, The Bi-State Transportation Technical Advisory Committee (BTTAC) which is comprised of representatives of The San Diego Association of Governments (SANDAG), The Southern California 
Association of Governments (SCAG), The Imperial Valley Association of Governments (IVAG), CALTRANS, The Office of the Secretary of Human Settlements and Public Works of Baja California (SAHOPE), the cities of San Diego and Calexico, and the municipalities of Tijuana, Mexicali, Ensenada, Tecate, and Playas de Rosarito in Baja California supported the preparation of a comprehensive binational plan for the area surrounding the San Ysidro Port of Entry, including the development of a joint strategy, work program and schedule.

The BTTAC also agreed to assist in obtaining funding for border planning and to participate and provide direction in the plan preparation and implementation stages.

Environmental Impact - None at this time. Staff will advise regarding the scope of Federal, State and local environmental review required.

Fiscal Impact - Can not be determined at this time. It is anticipated that funding resources will be needed to support this project. An action requested of the LU\&H Committee is to direct staff to seek Federal and State funding to support local resources for border planning. Initial work to develop the joint strategy and work plan will begin with existing staff resources from the cities of San Diego and Tijuana.

\section{BACKGROUND}

The San Diego/Tijuana region is expected to grow to about 5 million by the year 2010 . The San Ysidro/Tijuana Port of Entry is the busiest land border crossing in the world. Border crossings increased approximately 55 percent between 1987 and 1990 as did congestion, crossing time delays, pollution and other urban problems. In 1995, tpproximately $\mathbf{4 5}$ million combined vehicular and pedestrian traffic traversed the border both north and southbound at this location.

The purpose of this report is to bring the LU\&H Committee up to date on activities at the Dorder in the areas of plannir,y, public works, redevelopment, and economic development; to describe what both cities are doing and propose to do; and to coek further direction and support for the binational border planning program.

\section{Agreement for Binational Cooperation between the Cities of San Diego and Tijuana}

The Mayors of San Diego and Tijuana signed an agreement for binational cooperation in April, 1993. (See Attachment 1). Both City Governments of Tijuana and San Diego recognize a mutual interest and the need to facilitate the sharing of information and other cooperative efforts on issues affecting their common border. To carry out the 
objectives of the agreement, a committee chaired by the Mayors of Tijuana and San Diego and co-chaired by the City Managers of both cities was established. An equal number of members from each City lead Joint Working groups or Sub-committees on various topics.

On July 31,1996 the Mayors ratified their joint work plans for 1996-1997. These work plans form the basis for binational cooperation in the areas of emergency management, water and sewer, public works and service, public safety, environment and recycling, libraries, arts, recreation and culture, planning and land use, economic development, border transportation and technology. The work blans for both the Planning and Land Use and Economic_Development Sub-commimees include direction to undertake a binational project for the area surrounding the San Ysidro/Tijuana Border Crossing.

The binational project is to be a joint effort with staff from both the cities of San Diego and Tijuana working as a team. The preparation of a binational plan must also be coordinated with the work of the private sector, other agencies and organizations from both countries, and must involve the participation of citizens from both sides of the border.

\section{Adopted Plans}

A total of ten development plans (seven on the US side of border and three on the Mexico side of the border) provide broad policies for the future of communities located along the San Diego/Tijuana border corridor. These plans address issues related to, but not limited to land use, transportation, public facilities, environmental preservation, and urban design. A brief description of these plans is included in Attachment 2. In addition to plans, there are many studies, publications and research documents dealing with border issues.

\section{Need for Joint Coordination of Proposals and Schedules}

San Diego and Tijuana form a single interdependent region but have different economies, laws, development processes and cultures. Over 50 entities (see Attachment 3) from both countries are involved in border related issues at the San Ysidro/Tijuana Port of Entry. Many plans and projects are proposed for the border region but no single agency has coordinating authority in this area. Efforts to address commoi, Dorder problems have been unilateral and maguttileu, and have lacked a comprehensive approach. The future of this reaion needs a binational approach that maximizes the opportunities for social, physical and economic prosperity oftered by a border rocation.

The Mayors Binational Planning and Coordination Committee provides the structure for the City of San Diego and the City of Tijuana to coordinate plans and proposals, and 
work together in the preparation and implementation of a Binational Plan for the area of influence of the San Ysidro/Tijuana Port of Entry.

\section{DISCUSSION}

\section{Major Issues/Questions/Challenges}

Among the challenges facing us in this binational planning effort are the following:

1. There are many agencies, organizations and citizen groups on both sides of the border expressing willingness and commitment to find solutions to border problems (see Attachment 3). All interested parties need to be included and consulted in the development of a binational plan. What cumrnunication structure would ensure wide participation in the planning proness?

2. The forms of government, financial resources, cultural attitudes, decision-making and planning processes are different on both sides of the border, often making synchronized actions difficult to accomplish. The policies and proposals of a binational plan must be acceptable to both countries, and compatible with the needs and the laws of both countries. How can differences be reconciled? What approaches would result in a successful joint effort?

3. The communities adjacent to the San Ysidro/Tijuana Port of Entry are subjected to traffic, environmental and crime-related problems created by issues and needs of national and international proportions. There is evidence of increasing border-related violence and illegal activities spreading over nearby border neighborhoods. There is wear and tear on these neighborhoods caused by millions of border crossings. How can we mitigate negative border impacts on these communities?

4. The potential for commerce and economic prosperity at the San Ysidro/Tijuana Port of Entry is not even remotely realized. On both sides of the border there are several underutilized and large vacant parcels in government ownership, single ownership and small partnerships awaiting the right opportunity for development. What kind of land uses and activities would be most appropriate at the San Ysidro/Tijuana Port of Entry? How can this area be developed to achieve maximum economic potential?

5. The San Ysidro/Tijuana Port of Entry is presently chaotic, dysfunctional and intimidating. The channelization of vehicular traffic is confusing, pedestrian routes are indirect, unpleasant and often dangerous. Public transit terminates abruptly at the border with no further direction to the user on where to proceed next. How can the circulation of vehicles, pedestrians and transit be modified to achieve optimal efficiency? 
6. The image of the San Ysidro/Tijuana border area needs improvement. There is noise pollution, visual blight, poor circulation linkages and underutilized and poorly coordinated land uses. There are also serious maintenance problems, lack of adequate signage and information assistance, and limited amenities and basic services such as restrooms, telephones and lighting to serve border users. There are no visual elements that indicate that this is a major gateway between two countries. Anticipated increases in the intensity of the movement of people and goods will worsen the situation. How can this border area be transformed into a positive, exciting and safe place?

\section{Anticipated Work Program/Tasks}

The binational effort will address the impacts of proposed projects in the area surrounding the San Ysidro/Tijuana Port of Entry. More specifically, the binational plan will include policies including but not limited to 12 multi-purpose commercial and cultural development; 2) binational multimodal transportation terminals and linkages; 3) direct and safe pedestrian crossings; 4) infrastructure needs; 5) land uses on large, vacant land on the US side of the border, 6) coordination of the developed "Zona Norte" on the Mexican side of the border, 7) redevelopment of the San Ysidro community; 8) mitigation of environmental problems; and 9) urban design considerations for the border area.

\section{Proposed Major Projects in Border Region}

There are 23 currently proposed major projects on both sides of the international border. The largest private project is the International Gateway of the Americas, a unique binational proposal by $\mathrm{C}$. Samuel Marasco, Chief Executive Officer of LandGrant Development. Other proposed major projects pertain to new border crossings, multimodal transportation facilities, energy plants, environmental protection, and commercial enterprises. Following is a brief description of these projects.

Attachment 5 shows the location of major projects in the San Diego/Tijuana region. Attachment 6 shows those projects located around the San Ysidro/Tijuana Port of Entry.

\section{BINATIONAL PROJECTS}

1. International Gateway of the Americas - This proposal spans both countries and provides alternatives for transforming this presently unattractive border crossing area into a new and exciting environment. The centerpiece of the proposed project is a unique retail, hotel, office and entertainment complex that bridges the US/Mexico border creating a distinct and memorable place for the meeting of two cultures. The multi-faceted proposal includes a large shopping and restaurant area that can be accessed through new customs and immigration points from both sides of the border. The project proposes to join the two nations through a magnificent and symbolic new 
bridge and through multi modal linkages, thus creating a world class border crossing.

i his redevelopment proposal has been presented to many organizations and agencies . in the public and private sectors locally and in Mexico. An Exclusive Negotiating Agreement (ENA) with the San Diego Redevelopment Agency is being prepared and processed separately. This Agreement is scheduled to go before the Redevelopment Agency on July 15, 1997.

An ENA as utilized in California Redevelopment Law sets forth time lines and the conditions for studying a particular proposal as other necessary documents for entering into subsequent agreements are prepared. An ENA gives exclusive rights to a developer for a limited period of time to allow for identification of strategies obtained through public input and refinement of proposals as necessary. A tentative schedule for border planning is included in Attachment 7. (Project Leads: LandGrant Development \& City of San Diego Redevelopment Agency).

2. Otay Mesa II Port of Entry - A proposed new border crossing located approximately two miles east of the existing Otay Mesa Port of Entry. (Project Lead: County of San Diego).

3. San Diego \& Arizona Eastern Desert Line - A proposal to re-open the existing railway and restore service between San Diego and the Imperial Valley with continuing service to the east. (Project Lead: Metropolitan Transit Development Board).

4. Virginia Avenue Border Crossing - A proposal to re-open a closed border crossing point to meet future crossing demands. One alternative includes the designation of a crossing for southbound vehicular traffic only. A second alternative considers a northbound crossing only, limited to high occupancy and transit vehicles. Both alternatives incorporate pedestrian crossings. (Project Leads: Federal Governments of the US and Mexico).

5. Parallel System/Border Sewage Improvement Project - An international wastewater treatment plant and related facilities whose objective is to reduce the amount of untreated effluent entering the San Diego region from Tijuana. This project will also reduce adverse coastal and marine impacts and increase potential for future reuse of reclaimed wastewater. (Project Lead: International Boundary and Water Commission).

\section{UNITED STATES PROJECTS}

1. San Ysidro Intermodal Transportation Facility - A study to build an intermodal center east of Interstate 5 in the vicinity of the San Ysidro Trolley Station. Alternatives under consideration propose track realignments, new access roads, private property acquisition, elimination of vehicular traffic to create a pedestrian plaza, staging areas for 
buses, jitneys, shuttles and taxis; and better overall circulation. (Project Lead: Metropolitan Transit Development Board).

2. RailTex - A proposed cargo transfer station (trucks and railroad) and accessory storage use easterly of E. Beyer Blvd. in San Ysidro. (Project Lead: RailTex).

3. State Route 905 - A freeway that needs to be constructed by the year 2000 in order to accommodate projected commercial traffic entering or leaving the existing Otay Mesa Port of Entry. (Project Lead: California Department of Transportation).

4. State Route 125 - A new freeway needed to connect north/south commercial traffic to the Interstate Highway System. Its southernmost section is being planned as toll freeway. (Project Lead: California Transportation Ventures).

5. State Route 11 - A new toll freeway via the proposed Otay Mesa II Port of Entry that would connect with State Routes 905 and 125, and with the Tijuana 2000 project described below. (Project Lead: California Department of Transportation).

6. Otay Mesa Road Widening - a proposed widening from four to six lanes to improve traffic flow which is expected to be completed in the spring of 1998. (Project Lead: City of San Diego).

7. UETA Duty Free Shop - A proposal to establish a Duty Free shop and parking facility in the vicinity of the San Ysidro/Tijuana Port of Entry. Preliminary design plans have been prepared. (Project Lead: Duty Free International Company).

8. Baja Mex Insurance Parking Facility - A proposal to purchase City property and combine with private property to install an 89-space parking lot. (Project Lead: Baja Mex Insurance Company).

9. Border Power Plant - A proposal to build a major electric power plant just north of the international line east of the existing Otay Mesa Port of Entry. Anticipated for 1999. (Project Leads: Pacific Gas and Electric and US Generating).

10. Brown Field Improvements - A private development team, Brown Field Aviation Park, is working with the City to obtain a long-term ground lease and to update the master plan for the airport. The planning process will include environmental analysis, runway alternatives, air space/air cargo/ aviation activity projections and financial feasibility. (Project Lead: Brown Field Aviation Park). 


\section{MEXICO PROJECTS}

1. Light Rail System (LRT) - A five phase project that will provide a direct connection to the San Diego Trolley and to populated areas of Tijuana. Scheduled to commence in late 1997 and to be completed in 1999. (Project Lead: City of Tijuana).

2. Tijuana 2000 - A proposed peripheral ring that would re-route vehicular traffic going to the coastal areas and southern communities of Baja California, and to the Abelardo L. Rodriguez Airport. The objective is to divert traffic away from the congested streets of the Tijuana central area. (Project Lead: Secretary of Public Works-SAHOPE).

3. International Avenue - A project to improve circulation in the vicinity of the International Border and between border crossirigs. (Project Lead: City of Tijuana).

4. Pedestrian Link from Border to Revolucion Avenue - A project to provide better and safer access to pedestrians coming into the City and to give a better image of Tijuana. This link is utilized by approximately $\mathbf{2 0}$ million people annually. (Project Lead: City of Tijuana).

5. Pedestrian Tourist Route - A proposal to install directional and orientation elements, new curbs and ramps and to remodel tourist attractions along the main pedestrian routes often used to return to the border crossing. (Project Lead: City of Tijuana).

6. Zapata Canyon in Colonia Libertad - A proposed new collector road serving Colonia Libertad, a neighborhood near the international line. (Project Lead: City of Tijuana).

7. Boulevard Bellas Artes - A proposed road to link Otay and La Presa zones. It will unify the northern, eastern and southern areas of the City of Tijuana. (Project Lead: City of Tijuana).

8. Otay and Matamoros - A proposed new road in the Otay zone of Tijuana. (Project Lead: City of Tijuana).

9. Boulevard Manuel J. Clouthier - A road intended to join the two industrial zones of Otay and Gato Bronco. (Project Lead: City of Tijuana). 


\section{CONCLUSION}

There is a need for a collective and unified vision for the future of the area of influence of the San Ysidro/Tijuana Port of Entry. The present fragmentation of planning decisions and implementation actions is nof effective or productive. The numerous proposals under discussion are time sensitive and must be coordinated and integrated into a single document that reflects the objectives and needs of both countries. Under the leadership of the cities of San Diego and Tijuana, the expectation is to reach regional agreement about the future of this area.

Respectfully submitted,

Approved: Jack McGrory, Zo-chair Binational Planning and Coordination Committee
Approved: Ádblfo Guerrero, Co-Chair Binational Planning and Coordination Committee

\section{STEPNER/EIP}

\section{ATTACHMENTS:}

1. Mayors Binational Agreement

2. Adopted Plans

3. Entities Involved in Binational Planning Issues at the San Ysidro/Tijuana Port of Entry

4. San Diego/Tijuana Region Map

5. San Diego/Tijuana Proposed Major Projects Map

6. San Ysidro/Tijuana Port of Entry Proposed Major Projects Map

7. Tentative Schedule for Border Planning Program 